Article

\title{
Controlling the Antimicrobial Action of Surface Modified Magnesium Hydroxide Nanoparticles
}

\author{
Ahmed F. Halbus ${ }^{1,2}$, Tommy S. Horozov ${ }^{1}$ and Vesselin N. Paunov ${ }^{1, *(D)}$ \\ 1 Department of Chemistry and Biochemistry, University of Hull, Hull HU67RX, UK; \\ a.f.al-mamoori@2014.hull.ac.uk (A.F.H.); t.s.horozov@hull.ac.uk (T.S.H.) \\ 2 Department of Chemistry, College of Science, University of Babylon, Hilla, Iraq \\ * Correspondence: V.N.Paunov@hull.ac.uk; Tel.:+44-1482-465660
}

Received: 17 February 2019; Accepted: 20 June 2019; Published: 25 June 2019

check for updates

\begin{abstract}
Magnesium hydroxide nanoparticles $\left(\mathrm{Mg}(\mathrm{OH})_{2} \mathrm{NPs}\right)$ have recently attracted significant attention due to their wide applications as environmentally friendly antimicrobial nanomaterials, with potentially low toxicity and low fabrication cost. Here, we describe the synthesis and characterisation of a range of surface modified $\mathrm{Mg}(\mathrm{OH})_{2} \mathrm{NPs}$, including particle size distribution, crystallite size, zeta potential, isoelectric point, X-ray diffraction (XRD), dynamic light scattering (DLS), scanning electron microscopy (SEM), thermogravimetric analysis (TGA), energy dispersive X-ray analysis (EDX), Fourier transform infrared spectroscopy (FTIR), and transmission electron microscopy (TEM). We explored the antimicrobial activity of the modified $\mathrm{Mg}(\mathrm{OH})_{2} \mathrm{NPs}$ on the microalgae (C. reinhardtii), yeast (S. cerevisiae) and Escherichia coli (E. coli). The viability of these cells was evaluated for various concentrations and exposure times with $\mathrm{Mg}(\mathrm{OH})_{2} \mathrm{NPs}$. It was discovered that the antimicrobial activity of the uncoated $\mathrm{Mg}(\mathrm{OH})_{2} \mathrm{NPs}$ on the viability of $C$. reinhardtii occurred at considerably lower particle concentrations than for S. cerevisiae and E. coli. Our results indicate that the antimicrobial activity of polyelectrolyte-coated $\mathrm{Mg}(\mathrm{OH})_{2} \mathrm{NPs}$ alternates with their surface charge. The anionic nanoparticles $\left(\mathrm{Mg}(\mathrm{OH})_{2} \mathrm{NPs} / \mathrm{PSS}\right)$ have much lower antibacterial activity than the cationic ones $\left(\mathrm{Mg}(\mathrm{OH})_{2} \mathrm{NPs} / \mathrm{PSS} / \mathrm{PAH}\right.$ and uncoated $\left.\mathrm{Mg}(\mathrm{OH})_{2} \mathrm{NPs}\right)$. These findings could be explained by the lower adhesion of the $\mathrm{Mg}(\mathrm{OH})_{2} \mathrm{NPs} / \mathrm{PSS}$ to the cell wall, because of electrostatic repulsion and the enhanced particle-cell adhesion due to electrostatic attraction in the case of cationic $\mathrm{Mg}(\mathrm{OH})_{2} \mathrm{NPs}$. The results can be potentially applied to control the cytotoxicity and the antimicrobial activity of other inorganic nanoparticles.
\end{abstract}

Keywords: $\mathrm{Mg}(\mathrm{OH})_{2} \mathrm{NPs}$; magnesium hydroxide; polyelectrolytes; poly (styrene sulfonate); poly (allyl amine) hydrochloride; antimicrobial nanoparticles; algae; yeast; bacteria; C. reinhardtii; S.cerevisiae; E. coli

\section{Introduction}

The increased proliferation of infectious illnesses that are caused by microorganisms found in food packaging, medical devices, water treatment systems, and domestic appliances has elicited increased interest [1-3]. The increased resistance of microorganisms against current biocides has caused great concern, particularly for individuals of compromised immune systems [4,5]. This has prompted expanded efforts to investigate new types of nanomaterials as antibacterial agents [6-8], which do not rely on the existing pathways of antimicrobial resistance. Recent studies have been concentrated on antibacterial inorganic nanoparticles, for example, metal oxide nanoparticles, like $\mathrm{ZnO}, \mathrm{MgO}$, $\mathrm{CuO}, \mathrm{Cu}_{2} \mathrm{O}, \mathrm{Al}_{2} \mathrm{O}_{3}, \mathrm{TiO}_{2}, \mathrm{CeO}_{2}$, and $\mathrm{Y}_{2} \mathrm{O}_{3}$; metals, e.g., copper, silver, gold etc., metal hydroxides, such as $\mathrm{Mg}(\mathrm{OH})_{2}$ as well as colloids made from biodegradable materials, such as chitosan, lignin, and dextran, loaded with antibacterial agents [9]. $\mathrm{Mg}(\mathrm{OH})_{2} \mathrm{NPs}$ have been successfully deployed as 
antifungal and antibacterial agents towards different microorganisms [10-12] and there are indications that they can be highly effective [13]. $\mathrm{Mg}(\mathrm{OH})_{2} \mathrm{NPs}$ have attracted significant attention over the years due to their wide applications in different fields as an environmentally friendly material with low cost of production [14-17] and they may be potentially used in pharmaceutical formulations [18-21]. However, a limited number of studies have investigated the antimicrobial effects of $\mathrm{Mg}(\mathrm{OH})_{2} \mathrm{NPs}$ and reported that the in vivo toxicity values are low, thus demonstrating that it has a non-toxic effect on humans in sensible amounts [22]. Recently, it has been reported that $\mathrm{Mg}(\mathrm{OH})_{2} \mathrm{NPs}$ were effective as antibacterial agents towards several bacteria, including E. coli, S. aureus, P. aeruginosa, and B. phytofirmans [23-28], and a number of studies have been focused on this new and effective antimicrobial agent [17]. Dong et al. have investigated the antibacterial action of $\mathrm{Mg}(\mathrm{OH})_{2} \mathrm{NPs}$ on Burkholderia phytofirmans and Escherichia coli [24]. Their results indicated that the $\mathrm{Mg}(\mathrm{OH})_{2} \mathrm{NPs}$ suspensions are effective towards B. phytofirmans and E. coli. Their study has also examined the role of the $\mathrm{OH}^{-}$and $\mathrm{Mg}^{2+}$ ions, which are naturally present in the $\mathrm{Mg}(\mathrm{OH})_{2} \mathrm{NPs}$ suspension, on the antimicrobial action. They showed that an alkaline medium of $\mathrm{pH} 10.4$, as well as an equivalent amount of $\mathrm{Mg}^{2+}$ ions in the aqueous solution. could not kill the bacteria [24]. They have also indicated that $\mathrm{Mg}(\mathrm{OH})_{2} \mathrm{NPs}$ can kill E. coli, even in dark conditions, which suggested that no photocatalytic properties are involved in their antibacterial action [23]. Hence, the antibacterial mechanism of $\mathrm{Mg}(\mathrm{OH})_{2} \mathrm{NPs}$ seems to be very different to those of other metal and metal-based compounds [28-31]. Pan et al. synthesised $\mathrm{Mg}(\mathrm{OH})_{2} \mathrm{NPs}$ from three different precursors $\left(\mathrm{MgCl}_{2}, \mathrm{MgSO}_{4}\right.$, and $\left.\mathrm{MgO}\right)$ and tested their antibacterial efficiency towards $E$. coli as a model Gram-negative bacteria [17]. Bactericidal examinations indicated that the antibacterial activity of $\mathrm{Mg}(\mathrm{OH})_{2} \mathrm{NPs}$ was inversely related to particle size. Their results also revealed that the ability of $\mathrm{Mg}(\mathrm{OH})_{2} \mathrm{NPs}$ to adhere on the bacterial cell walls decreased in the order: $\mathrm{Mg}(\mathrm{OH})_{2-\mathrm{MgCl}}>$ $\mathrm{Mg}(\mathrm{OH})_{2}-\mathrm{MgSO}_{4}>\mathrm{Mg}(\mathrm{OH})_{2}-\mathrm{MgO}$, which showed that the toxicity of the produced $\mathrm{Mg}(\mathrm{OH})_{2} \mathrm{NPs}$ may be caused by the electrostatic interaction induced by secondary adsorption of counter-ions. This means that the type of precursor magnesium salt that is used to produce the $\mathrm{Mg}(\mathrm{OH})_{2} \mathrm{NPs}$ by hydrolysis can greatly influence their antimicrobial properties by the secondary absorption of counter-ions on the particles surface. These authors propose that $\mathrm{Mg}(\mathrm{OH})_{2} \mathrm{NPs}$ adsorb on the negatively charged bacterial cell wall and somehow disrupt its integrity, and increase its permeability, which kills the bacteria [17].

In this article, we investigate the role of the polymer coating in the antimicrobial activity of $\mathrm{Mg}(\mathrm{OH})_{2}$ nanoparticles that were synthesised by the direct precipitation method. Three different types of microorganisms, C. reinhardtii, S.cerevisiae cells, and Gram-negative E. coli were used to examine the antimicrobial activity of the surface modified $\mathrm{Mg}(\mathrm{OH})_{2} \mathrm{NPs}$. In this study, we are interested in using the surface functionalized $\mathrm{Mg}(\mathrm{OH})_{2} \mathrm{NPs}$ as innovative anti-algal, anti-bacterial, and antifungal agents. As C. reinhardtii is a typical representative of the algae genre and S. cerevisiae is a fungal microorganism, they are a good proxy for these assessments. We explored the relationship between the antifungal and antibacterial effect of the particle size, surface charge, in addition to their adhesion to the microbial cell wall. The size of the $\mathrm{Mg}(\mathrm{OH})_{2} \mathrm{NPs}$ is likewise essential for their potential activity, as smaller particles have higher portability to relocate between the biological compartments [32]. Moreover, the surface charge of the $\mathrm{Mg}(\mathrm{OH})_{2} \mathrm{NPs}$ determines their ability to electrostatically interact with the biological membranes. The present study investigates the impact of the $\mathrm{Mg}(\mathrm{OH})_{2} \mathrm{NPs}$ concentration, their zeta potential, and particle size on the viability of C. reinhardtii, S.cerevisiae, and E. coli at different exposure times. We explore the antimicrobial activity and the nanoparticle internalisation between $C$. reinhardtii, S.cerevisiae, and E. coli. In our experiments with surface functionalized $\mathrm{Mg}(\mathrm{OH})_{2} \mathrm{NPs}$ on microbial cells, which were systematically done on C. reinhardtii, S.cerevisiae, and E. coli, we have tested their effect in the absence of growth media whose components may potentially interfere with the particle surface charge. This would lead to ambiguity in the results, depending of the media composition and concentration. To avoid this, we remove the microbial cells from the media prior to testing the effect of the surface functionalized $\mathrm{Mg}(\mathrm{OH})_{2} \mathrm{NPs}$ on them. We investigate the antibacterial activity of $\mathrm{Mg}(\mathrm{OH})_{2} \mathrm{NPs}$ that are coated with anionic and cationic polyelectrolytes. Our working hypothesis is that coating the $\mathrm{Mg}(\mathrm{OH})_{2} \mathrm{NPs}$ with cationic polyelectrolytes may enhance their antimicrobial activity, 
while coating them with anionic polyelectrolytes as an outer layer may lead to decreased antibacterial activity because of their electrostatic repulsion from the bacterial cell wall (Figure 1).

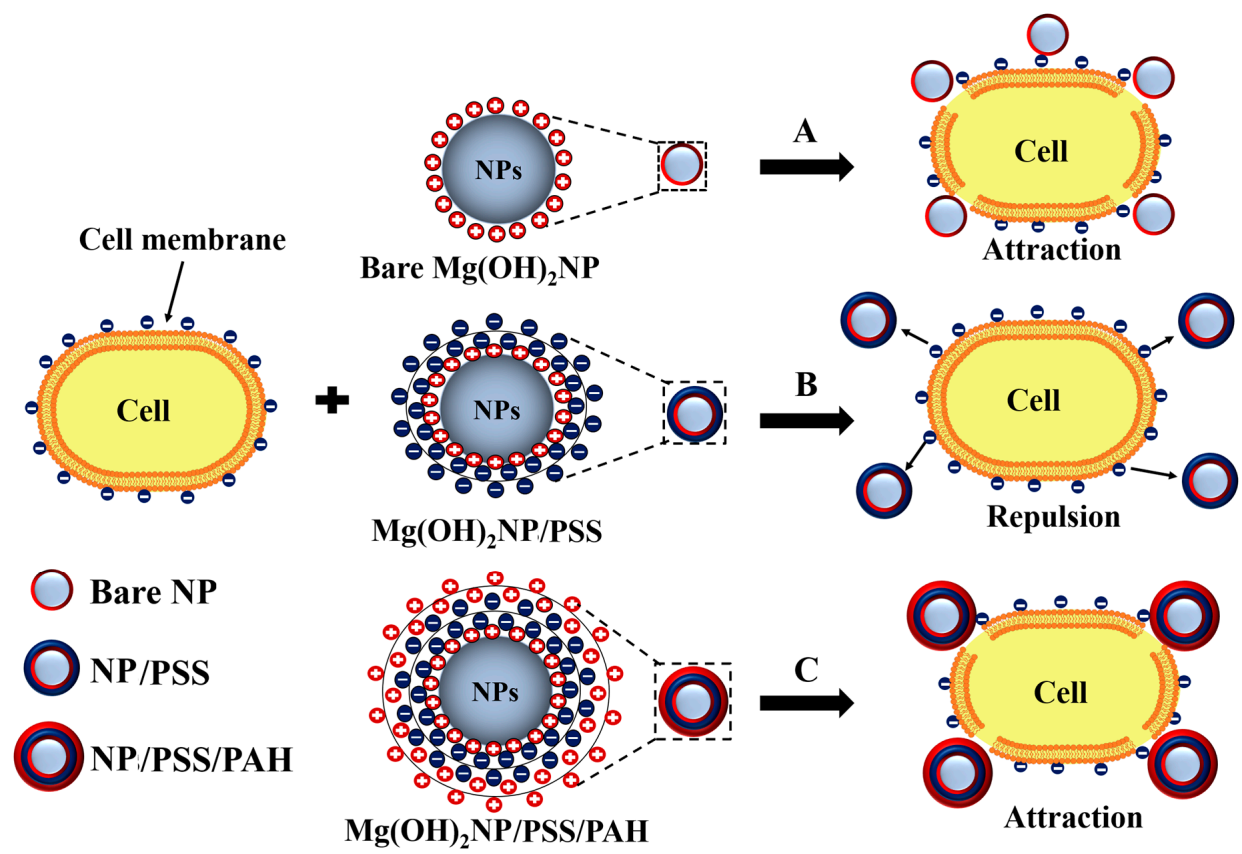

Figure 1. Schematic diagram showing the various contacting patterns between the bare and polyelectrolyte-coated $\mathrm{Mg}(\mathrm{OH})_{2} \mathrm{NPs}$ on cells. (A and $\mathbf{C}$ ) The adhesion of the uncoated and cationic polyelectrolyte-coated $\mathrm{Mg}(\mathrm{OH})_{2} \mathrm{NPs}$ to the cell wall surfaces is favoured due to their opposite surface charges. (B) The interaction between the anionic outer surface of the cell membrane and the $\mathrm{Mg}(\mathrm{OH})_{2} \mathrm{NPs}$ coated with anionic polyelectrolyte is repulsive. The cationic $\mathrm{Mg}(\mathrm{OH})_{2} \mathrm{NPs}$ and $\mathrm{Mg}(\mathrm{OH})_{2} \mathrm{NPs} / \mathrm{PSS} / \mathrm{PAH}$ nanoparticles are expected to be more effective against the microbial cells than the anionic $\mathrm{Mg}(\mathrm{OH})_{2} \mathrm{NPs} / \mathrm{PSS}$ particles.

\section{Materials and Methods}

\subsection{Materials}

Magnesium chloride (98\%, Sigma Aldrich, UK), sodium hydroxide (99.6\%, Fisher, UK), and fluorescein diacetate (FDA, 98\%, Fluka, UK) were used as supplied. Poly(sodium 4-styrene sulfonate) sodium salt (PSS), average M.W. $70 \mathrm{kDa}$, and poly(allylamine hydrochloride) (PAH), average M.W. $15 \mathrm{kDa}$, were purchased from Sigma Aldrich, UK. Deionized water that was produced by a Milli-Q reverse osmosis system (Millipore, UK) was used in all of the experiments. S.cerevisiae (from Sigma-Aldrich, UK) was cultured, as follows. $10 \mathrm{mg}$ of lyophilised S.cerevisiae (baker's yeast) was hydrated in $10 \mathrm{~mL}$ of pre-autoclaved deionized water at room temperature. Afterwards, $1 \mathrm{~mL}$ of the hydrated yeast suspension was added to $100 \mathrm{~mL}$ of the pre-autoclaved YPD culture media (yeast extract, peptone, and dextrose) and incubated for $48 \mathrm{~h}$ at $30^{\circ} \mathrm{C}$ [33]. Escherichia coli, which was sourced from Thermofisher (Invitrogen MAX Efficiency ${ }^{\mathrm{TM}} \mathrm{DH} 10 \mathrm{~B}^{\mathrm{TM}}$ ), was kindly provided for our antibacterial tests by Prof. Rotchell's group at the University of Hull, UK. E. coli was grown up using Luria-Bertani medium (LB medium) [34], which can be prepared from $1 \mathrm{~g}$ tryptone, $0.5 \mathrm{~g}$ yeast extract, and $1 \mathrm{~g}$ sodium chloride in $100 \mathrm{~mL}$ deionized water. Subsequently, these components were autoclaved for one hour at 1.5 bar at $125^{\circ} \mathrm{C}$. A few microlitres of the stock suspension of E. coli were dispersed in the autoclaved culture media next to the Bunsen burner once the culture media was cooled down to room temperature. The cultured E. coli was incubated with shaking at $25^{\circ} \mathrm{C}$ for $48 \mathrm{~h}$ to yield $5 \times 10^{5}-1 \times 10^{6}$ colony forming units per $\mathrm{mL}(\mathrm{CFU} / \mathrm{mL})$. Flickinger's group from North Carolina University, USA kindly provided Chlamydomonas reinhardtii (cc-124 strain). This microalgae culture was grown in Tris-Acetate-Phosphate (TAP) culture medium and incubated at a temperature of $30^{\circ} \mathrm{C}$. 
The C. reinhardtii culture media consisted of TAP salts $\left(\mathrm{NH}_{4} \mathrm{Cl} ; \mathrm{MgSO}_{4} \cdot 7 \mathrm{H}_{2} \mathrm{O}\right.$; and, $\left.\mathrm{CaCl}_{2} \cdot 2 \mathrm{H}_{2} \mathrm{O}\right)$, phosphate buffer solution (PBS), and Hutner's trace elements solution (EDTA disodium salt, $\mathrm{ZnSO}_{4}$. $\left.7 \mathrm{H}_{2} \mathrm{O}, \mathrm{H}_{3} \mathrm{BO}_{3}, \mathrm{MnCl}_{2} \cdot 4 \mathrm{H}_{2} \mathrm{O}, \mathrm{CoCl}_{2} \cdot 6 \mathrm{H}_{2} \mathrm{O}, \mathrm{CuSO}_{4} \cdot 5 \mathrm{H}_{2} \mathrm{O}, \mathrm{FeSO}_{4} \cdot 7 \mathrm{H}_{2} \mathrm{O},\left(\mathrm{NH}_{4}\right)_{6} \mathrm{Mo}_{7} \mathrm{O}_{24} \cdot 4 \mathrm{H}_{2} \mathrm{O}\right)$, all purchased from Sigma-Aldrich, UK. The microalgae batch was grown in TAP media at $\mathrm{pH} 7$ while being illuminated for $72 \mathrm{~h}$ by a white luminescent lamp with a light intensity of $60 \mathrm{~W} \mathrm{~m}^{-2}$ under constant stirring on a magnetic stirrer.

\subsection{Characterisation}

The $\mathrm{Mg}(\mathrm{OH})_{2} \mathrm{NPs}$ size distribution and the zeta potential were characterised by a Zetasizer Nano ZL instrument (Malvern, UK). A digital sonicator (Branson LTD) was utilized for dispersing the $\mathrm{Mg}(\mathrm{OH})_{2} \mathrm{NPs}$ samples at $40 \%$ amplitude for $15 \mathrm{~min}$ at $2.0 \mathrm{~s} \mathrm{ON} / 2.0 \mathrm{~s}$ OFF pulse time. The thermogravimetric analysis (TGA) of $\mathrm{Mg}(\mathrm{OH})_{2} \mathrm{NPs}$ was done using a Mettler Toledo TGA/DSC instrument under $\mathrm{N}_{2}$ atmosphere. The crystallite size of $\mathrm{Mg}(\mathrm{OH})_{2} \mathrm{NPs}$ at various temperatures was studied by X-ray diffraction (Siemens D5000 X-Ray Diffractometer at $0.15418 \mathrm{~nm}$ wavelength). A JEM 2011 (JEOL, Japan) Transmission Electron Microscopy (TEM) machine was used to characterise the particle size and the morphology of $\mathrm{Mg}(\mathrm{OH})_{2} \mathrm{NPs}$ on the microbial cells surface. The JEOL JSM-6480 LV SEM instrument was utilized for characterising the morphology of $\mathrm{Mg}(\mathrm{OH})_{2} \mathrm{NPs}$ with bacterial.

\subsection{Synthesis of $\mathrm{Mg}(\mathrm{OH})_{2} \mathrm{NPs}$}

The $\mathrm{Mg}(\mathrm{OH})_{2} \mathrm{NPs}$ were prepared from magnesium chloride $\left(\mathrm{MgCl}_{2}\right)$ as a source of magnesium ions and sodium hydroxide $(\mathrm{NaOH})$ aqueous solutions. Precipitation was induced by a dropwise addition of $0.4 \mathrm{M} \mathrm{NaOH}$ into the $0.2 \mathrm{M} \mathrm{MgCl}_{2}$ solution under continuous stirring at different reaction temperatures (i.e., $25^{\circ} \mathrm{C}, 50^{\circ} \mathrm{C}, 75^{\circ} \mathrm{C}$ and $100{ }^{\circ} \mathrm{C}$ ) for $1 \mathrm{~h}$. The white product was centrifuged and washed with copious amounts of high purity water and ethanol for the effective removal of impurities. The final product was dried at $80^{\circ} \mathrm{C}$ for $24 \mathrm{~h}$ [6]. Aqueous dispersions of the $\mathrm{Mg}(\mathrm{OH})_{2} \mathrm{NPs}$ were then prepared by dispersing $0.025 \mathrm{~g}$ of the $\mathrm{Mg}(\mathrm{OH})_{2}$ sample in $100 \mathrm{~mL}$ deionized water by using a digital sonicator (Branson Ltd.) at $40 \%$ of the maximum power for $15 \mathrm{~min}$ at $2 \mathrm{~s} \mathrm{ON} / 2 \mathrm{~s}$ OFF pulse time. Figure $\mathrm{S} 1$ shows a schematic diagram of the synthesis method of $\mathrm{Mg}(\mathrm{OH})_{2} \mathrm{NPs}$.

\subsection{Preparation of Polyelectrolyte-Coated $\mathrm{Mg}(\mathrm{OH})_{2} \mathrm{NPS}$}

Polyelectrolyte-coated $\mathrm{Mg}(\mathrm{OH})_{2} \mathrm{NPs}$ were prepared by using the $\mathrm{Mg}(\mathrm{OH})_{2} \mathrm{NPs}$ synthesised at a reaction temperature of $75^{\circ} \mathrm{C} .50 \mathrm{~mL}$ of $1000 \mu \mathrm{g} \mathrm{mL}{ }^{-1} \mathrm{Mg}(\mathrm{OH})_{2} \mathrm{NPs}$ dispersion in deionized water were added dropwise to an equal amount of $50 \mathrm{mg} \mathrm{mL}^{-1}$ PSS (M.W. $\sim 70 \mathrm{kDa}$ ) solution in $1 \mathrm{mM} \mathrm{NaCl}$. The samples were washed three times by centrifugation for $1 \mathrm{~h}$ at $10,000 \mathrm{rpm}$ to remove the excess of PSS after shaking for $1 \mathrm{~h}$ on orbital shaker. Finally, the PSS-coated $\mathrm{Mg}(\mathrm{OH})_{2} \mathrm{NPs}$ were re-dispersed in $50 \mathrm{~mL}$ deionized water [35] and the particle size and zeta potential measured by a Zetasizer Nano ZL instrument. To prepare the PAH-coated nanoparticles, the PSS-coated $\mathrm{Mg}(\mathrm{OH})_{2} \mathrm{NP}$ suspension was mixed dropwise with $50 \mathrm{~mL}$ of $50 \mathrm{mg} \mathrm{mL}^{-1}$ PAH (M.W. $15 \mathrm{kDa}$ ) that was dissolved in $1 \mathrm{mM} \mathrm{NaCl}$ solution. The mixture was shaken for $20 \mathrm{~min}$ and centrifuged three times at 10,000 rpm for one hour to yield $\mathrm{Mg}(\mathrm{OH})_{2} \mathrm{NPs} / \mathrm{PSS} / \mathrm{PAH}$.

\subsection{Antimicrobial Assay of Polyelectrolyte-Coated $\mathrm{Mg}(\mathrm{OH})_{2} \mathrm{NPs}$ on S.cerevisiae}

The effect of $\mathrm{Mg}(\mathrm{OH})_{2} \mathrm{NPs}$ on S.cerevisiae cells was examined after removing the cells from the culture media. $30 \mathrm{~mL}$ dispersion of S.cerevisiae cells were washed by centrifugation with deionized water three times, and then re-dispersed in $30 \mathrm{~mL}$ deionized water. $5 \mathrm{~mL}$ of S.cerevisiae cell dispersion in deionized water were incubated with $5 \mathrm{~mL} \mathrm{Mg}(\mathrm{OH})_{2} \mathrm{NPs}$ aqueous suspension upon increasing total particle concentrations $\left(0,250,500,1000,2500\right.$, and $\left.5000 \mu \mathrm{g} \mathrm{mL}{ }^{-1}\right)$ for $10 \mathrm{~min}, 6 \mathrm{~h}, 12 \mathrm{~h}$, and $24 \mathrm{~h}$. $1 \mathrm{~mL}$ of each incubated S.cerevisiae sample was centrifuged at $3500 \mathrm{rpm}$ for $4 \mathrm{~min}$ and washed with deionized water to remove the excess of $\mathrm{Mg}(\mathrm{OH})_{2} \mathrm{NPs}$. The S.cerevisiae cells were re-suspended in $1 \mathrm{~mL}$ of deionized water, then two drops of $1 \mathrm{mM}$ FDA solution in acetone were added to each sample and 
then mixed together for $15 \mathrm{~min}$. After that, the samples were washed three times with deionized water by centrifugation at $3500 \mathrm{rpm}$ for $4 \mathrm{~min}$. Finally, the viability of the cells was examined by fluorescence microscopy and an automatic cell counter (Nexcelom Cellometer Auto X4 Fluorescence). Similar experiments were utilized to test the effect of $\mathrm{Mg}(\mathrm{OH})_{2} \mathrm{NPs}$ that were coated with polyelectrolytes on the viability of S.cerevisiae.

\subsection{Antibacterial Assay of Polyelectrolyte-Coated $\mathrm{Mg}(\mathrm{OH})_{2} \mathrm{NPS}_{\mathrm{S}}$ on E. coli}

$10 \mathrm{~mL}$ of the E. coli culture grown in LB medium was washed, centrifuged three times with deionized water at $5000 \mathrm{rpm}$ for three minutes, and redispersed in $100 \mathrm{~mL}$ deionized water. Subsequently, $5 \mathrm{~mL}$ of the washed $E$. coli suspension were incubated with a series of $5 \mathrm{~mL}$ aliquots of aqueous dispersions of $\mathrm{Mg}(\mathrm{OH})_{2} \mathrm{NPs}$ of different concentrations $(0,250,500,750,1000,2500,5000$, and $\left.6000 \mu \mathrm{g} \mathrm{mL}^{-1}\right)$. After each incubation, $1 \mathrm{~mL}$ of each $E$. coli suspension sample was washed and re-suspended in $1 \mathrm{~mL}$ deionized water. Afterwards, $100 \mu \mathrm{L}$ of culture media free E. coli bacteria were incubated with $100 \mu \mathrm{L}$ of the BacTiter-Glo Microbial cell viability reagent in a white opaque 96-well solid flat bottom microplate, shaken for $30 \mathrm{~s}$, and then incubated for five minutes at $25^{\circ} \mathrm{C}$. The relative luminance was measured as a function of incubation time to find out the cell viability upon incubation with different concentration of $\mathrm{Mg}(\mathrm{OH})_{2} \mathrm{NPs}$. The same experiments were also repeated with polyelectrolyte-coated $\mathrm{Mg}(\mathrm{OH})_{2} \mathrm{NPs}$. This was done by incubating an aliquot of the E. coli suspension (diluted 10 times) with $\mathrm{Mg}(\mathrm{OH})_{2} \mathrm{NPs}$ that were coated with poly(sodium-4-styrenesolfonate and poly(allylamine hydrochloride) for up to $24 \mathrm{~h}$.

\subsection{Antialgal Activity of Polyelectrolyte-Coated $\mathrm{Mg}(\mathrm{OH})_{2} \mathrm{NPS}$ to C. reinhardtii}

$50 \mathrm{~mL}$ of $C$. reinhardtii culture were washed from the culture media three times by using deionized water and centrifugation, and finally re-dispersed in $30 \mathrm{~mL}$ deionized water. $5 \mathrm{~mL}$ of the washed $C$. reinhardtii cells were incubated with a series of $5 \mathrm{~mL}$ aliquots of aqueous $\mathrm{Mg}(\mathrm{OH})_{2} \mathrm{NPs}$ dispersions at different concentrations at $25^{\circ} \mathrm{C}$. A control sample of the same cells was treated in a similar way without any exposure to $\mathrm{Mg}(\mathrm{OH})_{2} \mathrm{NPs}$. After that, $1 \mathrm{~mL}$ of the $C$. reinhardtii suspension was taken from each treated sample and washed with deionized water to remove the excess of nanoparticles by centrifugation at $3500 \mathrm{rpm}$ for $4 \mathrm{~min}$. The C. reinhardtii cells were re-suspended in $1 \mathrm{~mL}$ deionized water, and two drops of $1 \mathrm{mM}$ FDA solution in acetone were added to each sample and mixed together for $15 \mathrm{~min}$. After that, the samples were washed three times with deionized water by centrifugation at $3500 \mathrm{rpm}$ for $4 \mathrm{~min}$. Finally, the automatic cell counter was utilized to assay the microalgae cell viability. The same method was used to test the effect of $\mathrm{Mg}(\mathrm{OH})_{2} \mathrm{NPs}$ that were coated with PSS and PAH on the viability of $C$. reinhardtii, which were incubated at different particle concentrations for various exposure times.

\subsection{SEM and TEM Sample Preparation Protocol for C. reinhardtii, S.cerevisiae and E. coli after Exposure to Bare- and Polyelectrolyte-Coated $\mathrm{Mg}(\mathrm{OH})_{2} \mathrm{NPS}$}

The C. reinhardtii, S.cerevisiae and E. coli were washed by centrifugation and then fixed with $2.5 \%$ glutaraldehyde at room temperature for two hours in $0.1 \mathrm{M}$ cacodylate buffer $\mathrm{pH} 7.2$ after incubation with the bare- or polyelectrolyte-coated $\mathrm{Mg}(\mathrm{OH})_{2} \mathrm{NPs}$ of various concentrations. These samples were then post-fixed in $1 \%$ osmium tetroxide for $1 \mathrm{~h}$, and then dehydrated in a range of ethanol-water mixtures with an increasing ethanol content from $50 \mathrm{vol} \%$ up to $100 \mathrm{vol} \%$, followed by a critical point drying. After incubation with $\mathrm{Mg}(\mathrm{OH})_{2} \mathrm{NPs}$, the microbial cells were prepared for TEM imaging while using the following procedure. The cells were washed with deionized water to remove the excess of $\mathrm{Mg}(\mathrm{OH})_{2} \mathrm{NPs}$ by centrifugation at $500 \mathrm{rpm}$ and then fixed in $2 \mathrm{wt} \%$ glutaraldehyde for one hour at room temperature. This was followed by a treatment with $1 \mathrm{wt} \%$ osmium tetroxide for one hour. Subsequently, the samples were incubated for one hour with $2.5 \%$ uranyl acetate and washed with aqueous ethanol solutions of increasing concentration, as described above. After standard dehydration, the microbial samples were embedded in fresh epoxy/Araldite at $60{ }^{\circ} \mathrm{C}$ for two days, left for two 
days at room temperature, and sectioned with an ultra-microtome. SEM and TEM imaged microbial samples before and after the nanoparticle treatment.

\subsection{Zeta Potential Measurements of the C. reinhardtii, S.cerevisiae and E. coli cells after treatment with $\mathrm{Mg}(\mathrm{OH})_{2} \mathrm{NPS}$}

The changes of surface charge of $C$. reinhardtii, S.cerevisiae, and $E$. coli after exposure to $\mathrm{Mg}(\mathrm{OH})_{2} \mathrm{NPs}$ at different concentrations $\left(0,250,500,750,1000,2500,5000\right.$, and $\left.6000 \mu \mathrm{g} \mathrm{mL}^{-1}\right)$ were determined by a Zetasizer Nano ZL instrument (Malvern, UK). The cells were removed from the excess of $\mathrm{Mg}(\mathrm{OH})_{2} \mathrm{NPs}$ in the aqueous phase by centrifugation, and then dispersed in deionized water. For each sample, an appropriate amount of undiluted solution was placed into the cuvette, and an average zeta potential value was obtained from three individual measurements. The solution media was deionized water in all of the zeta potential measurements.

\subsection{MIC of Non-modified and PSS/PAH-coated $\mathrm{Mg}(\mathrm{OH})_{2} \mathrm{NPs}$ on Microbial Cells}

The following protocol was used to determine the Minimal Inhibitory Concentration (MIC) of $\mathrm{Mg}(\mathrm{OH})_{2} \mathrm{NPs}$ and PSS/PAH-coated $\mathrm{Mg}(\mathrm{OH})_{2} \mathrm{NPs}$ on cells. A negative control of $100 \mu \mathrm{L}$ of LB medium was added to the first line of wells of a 96 well plate. $50 \mu \mathrm{L}$ of LB medium were added to the treatment wells and the positive bacteria control wells. A stock solution of $\mathrm{Mg}(\mathrm{OH})_{2} \mathrm{NPs}$ and PSS/PAH-coated $\mathrm{Mg}(\mathrm{OH})_{2} \mathrm{NPs}$ was created in fresh LB medium to a total volume of $10 \mathrm{~mL} .50 \mu \mathrm{L}$ of this formulation ware added to the first line of treatment wells, and serial diluted 1:2 across the 96 well plate, which ensured that it was mixed by pipetting up and down within each well. An overnight culture of E. coli was diluted into a sterilised $0.85 \%$ saline until an absorbance reading between 0.08 and 0.12 at $625 \mathrm{~nm}$ was obtained on a spectrophotometer ( 0.5 Mcfarland Standard). The saline diluted bacteria were further diluted 1:150 into LB (10 mL LB $+66.67 \mu \mathrm{L}$ of bacteria in saline solution) yielding a $10 \mathrm{~mL}$ stock containing $5 \times 10^{5}-1 \times 10^{6}$ cells per $\mathrm{mL}$. $50 \mu \mathrm{L}$ from this bacteria stock were added to each treatment and positive bacteria control wells, seeding with $2.5 \times 10^{4}-5 \times 10^{4}$ cells per well. Each well contained a final volume of $100 \mu \mathrm{L}$, with decreasing concentrations of treatment on equal amounts of bacteria. The plate was incubated for $24 \mathrm{~h}$ at $37^{\circ} \mathrm{C}$. After incubation, $20 \mu \mathrm{L}$ of resazurin solution were added to each well. The MIC was determined from the lowest concentration treatment, which inhibited growth.

\section{Results and Discussion}

\subsection{Preparation and Characterisation of $\mathrm{Mg}(\mathrm{OH})_{2} \mathrm{NPs}$}

The mean hydrodynamic diameter and zeta potential of the $\mathrm{Mg}(\mathrm{OH})_{2} \mathrm{NPs}$ in deionized water were measured by the dynamic light scattering instrument (DLS) of suspensions that were prepared by dispersing $0.025 \mathrm{~g}$ of $\mathrm{Mg}(\mathrm{OH})_{2} \mathrm{NPs}$ sample in $100 \mathrm{~mL}$ of deionized water by a digital sonicator. The average hydrodynamic diameter of $\mathrm{Mg}(\mathrm{OH})_{2} \mathrm{NPs}$ was found to be $69 \pm 10 \mathrm{~nm}$ and their zeta potential was $+30 \pm 6 \mathrm{mV}$, as shown in Figure S2 and Figure S3. The thermo gravimetric analysis (TGA) that was carried out between 50 and $1000{ }^{\circ} \mathrm{C}$, as shown in Figure S4A, indicated that the $\mathrm{Mg}(\mathrm{OH})_{2}$ sample was stable up to $270^{\circ} \mathrm{C}$. Subsequently, the endothermic peak corresponding to the removal of the adsorbed water molecules took place between $270-300^{\circ} \mathrm{C}$, as also reported by other authors [36]. The major weight loss step has been found in the temperature range of $300-450{ }^{\circ} \mathrm{C}$, which is due to the transition phase, corresponding to the decomposition of $\mathrm{Mg}(\mathrm{OH})_{2} \mathrm{NPs}$ to $\mathrm{MgO}$. The TGA curve exhibits a total mass loss equal to $29.46 \%$, which is slightly lower than the calculated mass loss (30.8\%) that is attributed to the complete dehydroxylation process of $\mathrm{Mg}(\mathrm{OH})_{2}$. This result also agrees with previous studies [36-38]. An Energy dispersive X-ray Diffraction (EDX) analysis was carried out on the synthesised $\mathrm{Mg}(\mathrm{OH})_{2} \mathrm{NPs}$ to verify the elemental composition. The EDX data in Figure S4B confirm the presence of magnesium and oxygen signals in the $\mathrm{Mg}(\mathrm{OH})_{2} \mathrm{NPs}$ sample. The elemental analysis of the $\mathrm{Mg}(\mathrm{OH})_{2} \mathrm{NPs}$ yielded $36.59 \%$ of magnesium and $59.94 \%$ of oxygen, which indicates that the formed $\mathrm{Mg}(\mathrm{OH})_{2} \mathrm{NPs}$ were in its highly purified form and in agreement with previous studies [24]. 
We studied the effect of annealing temperature on the particle size of $\mathrm{Mg}(\mathrm{OH})_{2} \mathrm{NPs}$ for the synthesis that was done at various reaction temperature $\left(25^{\circ} \mathrm{C}, 50{ }^{\circ} \mathrm{C}, 75^{\circ} \mathrm{C}\right.$, and $\left.100{ }^{\circ} \mathrm{C}\right)$. Figure $\mathrm{S} 4 \mathrm{C}$ shows the impact of the temperature of the reaction mixture on the size of $\mathrm{Mg}(\mathrm{OH})_{2} \mathrm{NPs}$ for one hour. $\mathrm{Mg}(\mathrm{OH})_{2} \mathrm{NPs}$ of lower average size were produced at $75^{\circ} \mathrm{C}$ and $100{ }^{\circ} \mathrm{C}$, while larger particles were created at $25^{\circ} \mathrm{C}$ and $50{ }^{\circ} \mathrm{C}$. Therefore, $75^{\circ} \mathrm{C}$ and $100{ }^{\circ} \mathrm{C}$ were the optimal temperatures for the production of $\mathrm{Mg}(\mathrm{OH})_{2} \mathrm{NPs}$.

The zeta potential and particle size of the produced $\mathrm{Mg}(\mathrm{OH})_{2} \mathrm{NPs}$ was measured at $\mathrm{pH}$ in the range 3-12 and the results are shown in Figure S4D. The isoelectric point of the non-coated $\mathrm{Mg}(\mathrm{OH})_{2} \mathrm{NPs}$ was approximately at $\mathrm{pH} 11.7$, i.e., the bare $\mathrm{Mg}(\mathrm{OH})_{2} \mathrm{NPs}$ are cationic at neutral $\mathrm{pH}$. As it can be seen from Figure S4D, the zeta potential decreases and the particle size increases upon the increase of $\mathrm{pH}$. The aggregation of $\mathrm{Mg}(\mathrm{OH})_{2} \mathrm{NPs}$ occurs above $\mathrm{pH}$ 8.5. The Fourier transform infrared spectroscopy (FTIR) spectrum of the $\mathrm{Mg}(\mathrm{OH})_{2} \mathrm{NPs}$ synthesised using a magnesium chloride solution at different reaction temperatures is shown in Figure S5 (ESI). The sharp and intense $3700 \mathrm{~cm}^{-1}$ FTIR peak corresponds to the $\mathrm{Mg}(\mathrm{OH})_{2}$ asymmetric $\mathrm{O}-\mathrm{H}$ stretching. The band at $1400 \mathrm{~cm}^{-1}$ is due to the water $\mathrm{O}-\mathrm{H}$ stretch. The strong and wide $570 \mathrm{~cm}^{-1}$ peak is due to $\mathrm{Mg}-\mathrm{O}$ stretching. No other absorption peaks from impurities were detected. This result indicates that the $\mathrm{Mg}(\mathrm{OH})_{2}$ that was obtained had higher purity and it is also in agreement with previous studies $[39,40]$.

\subsection{Effect of the Precipitation Temperature on the Crystallite Size of the Synthesised $\mathrm{Mg}(\mathrm{OH})_{2} \mathrm{NPS}$}

Figure 2 shows the XRD pattern of $\mathrm{Mg}(\mathrm{OH})_{2} \mathrm{NPs}$ samples that were obtained at various reaction temperatures $25{ }^{\circ} \mathrm{C}, 50{ }^{\circ} \mathrm{C}, 75^{\circ} \mathrm{C}$, and $100{ }^{\circ} \mathrm{C}$ while using magnesium chloride as a precursor. The diffraction peaks are in agreement with the hexagonal structure of $\mathrm{Mg}(\mathrm{OH})_{2} \mathrm{NPs}$ according to Joint Committee on Powder Diffraction Standards (JCPDS) Card No. 00-044-1482, which indicates that no apparent impurities are detected. The average crystallite size of $\mathrm{Mg}(\mathrm{OH})_{2} \mathrm{NPs}$ was calculated by using the Scherrer equation, $D=K \lambda / \beta \cos \theta$, were $D$ is the crystallite size in $\mathrm{nm}, K$ is a dimensionless shape constant taken as $0.94,2 \theta$ is the diffraction angle, $\lambda$ is the wavelength of the $\mathrm{X}$-ray radiation $(\mathrm{CuK} \alpha=$ $0.15406 \mathrm{~nm}$ ), and $\beta$ is the full width at the half-maximum (FWHM) of the diffraction peak.
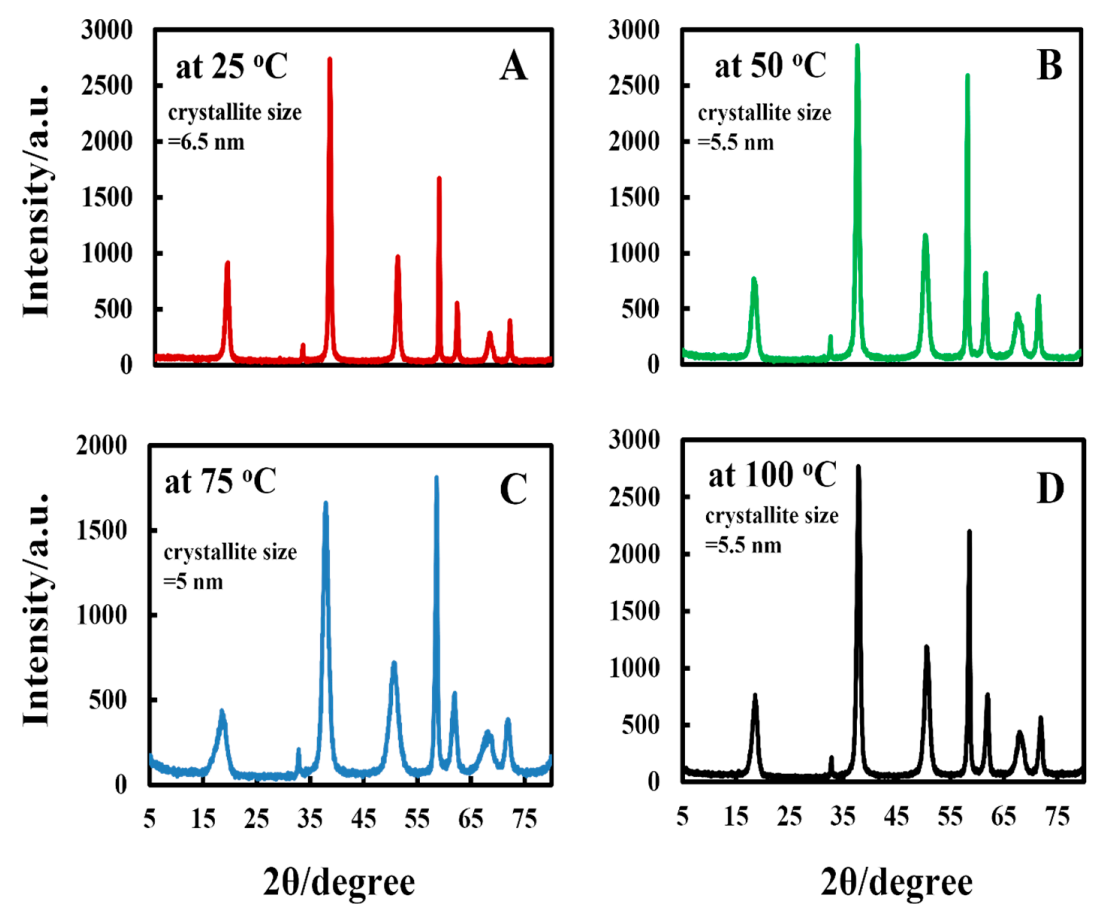

Figure 2. Comparison of the X-ray pattern of $\mathrm{Mg}(\mathrm{OH})_{2} \mathrm{NPs}$ precipitated at $25^{\circ} \mathrm{C}(\mathbf{A}), 50{ }^{\circ} \mathrm{C}(\mathbf{B}), 75^{\circ} \mathrm{C}$ (C), and $100^{\circ} \mathrm{C}(\mathbf{D})$. 


\subsection{Polyelectrolyte-Functionalized $\mathrm{Mg}(\mathrm{OH})_{2} \mathrm{NPs}$}

We coated $69 \mathrm{~nm} \mathrm{Mg}(\mathrm{OH})_{2} \mathrm{NPs}$ with two subsequent layers of PSS and PAH via the procedures explained above [35]. Figure $3 \mathrm{~A}$ shows the zeta potential of the coated $\mathrm{Mg}(\mathrm{OH})_{2} \mathrm{NPs}$ as a function of the number of polyelectrolyte layers. The zeta potential of the $\mathrm{Mg}(\mathrm{OH})_{2} \mathrm{NPs}$ changed from approximately $+30 \mathrm{mV}$ to $-36 \mathrm{mV}$ for $\mathrm{Mg}(\mathrm{OH})_{2} \mathrm{NPs} / \mathrm{PSS}$. Further coating with PAH yielded positively charged $\mathrm{Mg}(\mathrm{OH})_{2} \mathrm{NPs} / \mathrm{PSS} / \mathrm{PAH}$ with a zeta potential of $+51 \mathrm{mV}$. As expected, the particle surface charge alternates with the addition of the oppositely charged polyelectrolyte layer. Figure 3B shows that the coated NPs size increases after every subsequent polyelectrolyte coating due to partial aggregation.
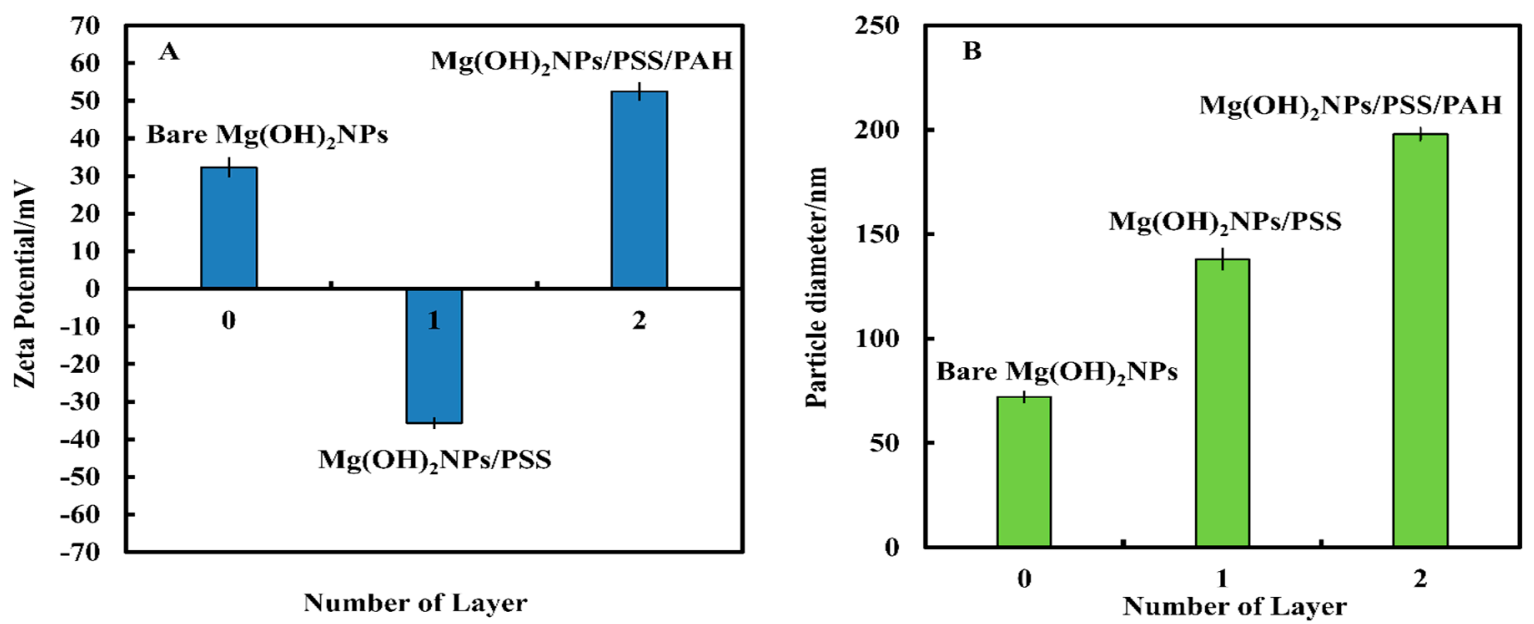

Figure 3. (A) The zeta potential and (B) particle size of bare-and polyelectrolyte-coated $\mathrm{Mg}(\mathrm{OH})_{2} \mathrm{NPs}$.

\subsection{Antimicrobial Assay of Bare $\mathrm{Mg}(\mathrm{OH})_{2} \mathrm{NPS}$ on S.cerevisiae, C. reinhardtii and E. coli}

We compared the antimicrobial activity of bare $\mathrm{Mg}(\mathrm{OH})_{2} \mathrm{NPs}$ on C. reinhardtii, S. cerevisiae, and $E$. coli, and Figure 4 shows the cell viability. We incubated samples of S.cerevisiae cells with dispersed $\mathrm{Mg}(\mathrm{OH})_{2} \mathrm{NPs}$ at different particle concentrations $\left(0,250,500,1000,2500\right.$, and $\left.5000 \mu \mathrm{g} \mathrm{mL}^{-1}\right)$ for different periods of time, up to one day. Subsequently, an aliquot of every sample was taken to examine the number of viable S.cerevisiae cells while using an automatic cell counter by FDA cell viability assay. Figure $4 \mathrm{~A}$ shows the percentage of viable S.cerevisiae cells at various incubation times (10 min., $6 \mathrm{~h}$, $12 \mathrm{~h}$, and $24 \mathrm{~h}$ ). One can see that the percentage of viable S.cerevisiae after $10 \mathrm{~min}$ incubation is at the same level as in the untreated sample. After $6 \mathrm{~h}$ of incubation, no measurable antimicrobial effect is noticed up to $500 \mu \mathrm{g} \mathrm{mL}^{-1} \mathrm{Mg}(\mathrm{OH})_{2} \mathrm{NPs}$; however, antimicrobial activity is observed at 1000,2500 , and $5000 \mu \mathrm{g} \mathrm{mL} \mathrm{m}^{-1} \mathrm{Mg}(\mathrm{OH})_{2} \mathrm{NPs}$. After $12 \mathrm{~h}$, the viability of S.cerevisiae sharply decreases at particle concentrations in the range $500-5000 \mu \mathrm{g} \mathrm{mL}^{-1}$. After one day of incubation, concentrations higher than $250 \mu \mathrm{g} \mathrm{mL} \mathrm{L}^{-1}$ bare $\mathrm{Mg}(\mathrm{OH})_{2} \mathrm{NPs}$ showed measurable antimicrobial activity towards S.cerevisiae. The optical microscopy examination of these samples suggests that the S.cerevisiae cells aggregate at a high particle concentration. Our results indicate a strong decline of the S.cerevisiae cell viability at concentrations above $1000 \mu \mathrm{g} \mathrm{mL}{ }^{-1}$ bare $\mathrm{Mg}(\mathrm{OH})_{2} \mathrm{NPs}$. Figure S15 (ESI) shows the same data, as in Figure $4 \mathrm{~A}-\mathrm{C}$ in $\mathrm{CFU} \mathrm{mL}^{-1}$.

The data in Figure 4A suggest that, at high concentrations of bare $\mathrm{Mg}(\mathrm{OH})_{2} \mathrm{NPs}$, they electrostatically adhere to the negatively charged cell membranes, which subsequently kills the cells. The attachment of $\mathrm{Mg}(\mathrm{OH})_{2} \mathrm{NPs}$ to the cells was also examined by TEM imaging. Figure $5 \mathrm{~A}, \mathrm{C}$ show TEM images of the S.cerevisiae cells before and after treatment with $1000 \mu \mathrm{g} \mathrm{mL}{ }^{-1} \mathrm{Mg}(\mathrm{OH})_{2} \mathrm{NPs}$ solution for $24 \mathrm{~h}$. Those are compared with the untreated samples of S.cerevisiae that are shown in Figure 5A,B. The TEM images show that, before the treatment (Figure 5A), the membrane of the S.cerevisiae cells is regular and smooth, the treatment with $1000 \mu \mathrm{g} \mathrm{mL}{ }^{-1} \mathrm{Mg}(\mathrm{OH})_{2} \mathrm{NPs}$ leads to a significant accumulation of $\mathrm{Mg}(\mathrm{OH})_{2} \mathrm{NPs}$ on the external wall of S.cerevisiae at such a high particle concentration (Figure 5C). 

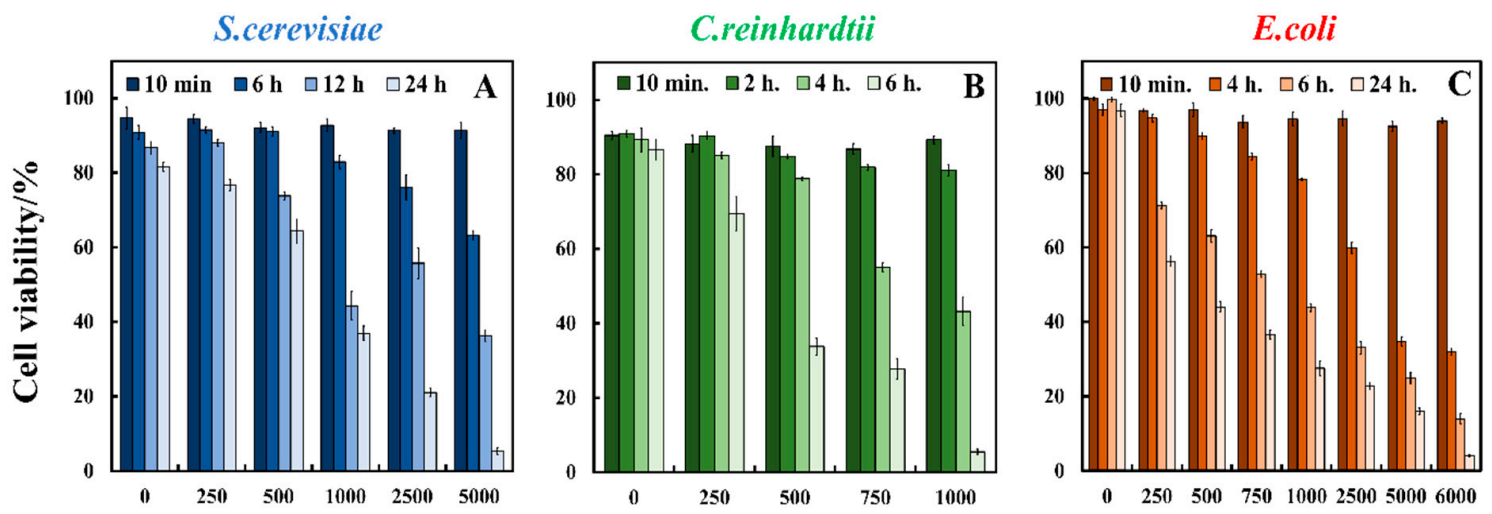

$\mathrm{Mg}(\mathrm{OH})_{2} \mathrm{NPs}$ concentration/ $\mu \mathrm{g} \mathrm{mL}^{-1}$

Figure 4. The antimicrobial activity of bare $\mathrm{Mg}(\mathrm{OH})_{2} \mathrm{NPs}$ on (A) S.cerevisiae (B) C. reinhardtii and (C) E. coli at various particle concentrations. The cells were incubated with the $\mathrm{Mg}(\mathrm{OH})_{2} \mathrm{NPs}$ at different periods of time shown.
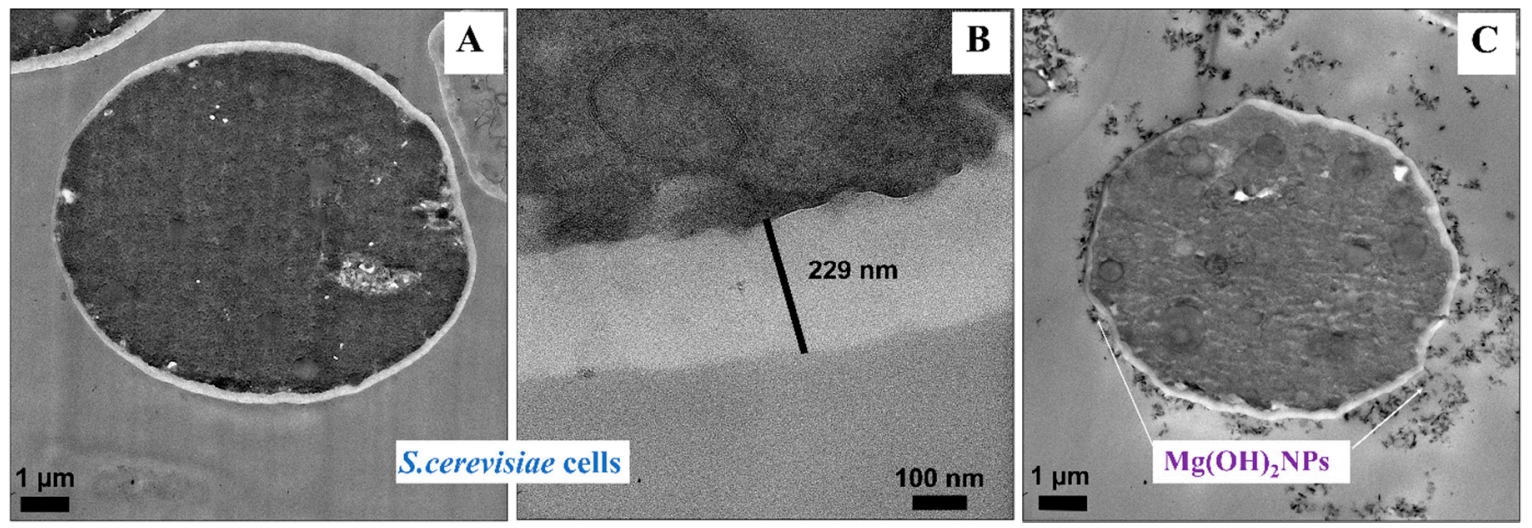

Figure 5. Transmission electron microscopy (TEM) images of S. cerevisiae after being incubated for one day with bare $\mathrm{Mg}(\mathrm{OH})_{2} \mathrm{NPs}$ : (A) A control sample without $\mathrm{Mg}(\mathrm{OH})_{2} \mathrm{NPs}$. (B) A high-resolution TEM image of the S. cerevisiae wall without $\mathrm{Mg}(\mathrm{OH})_{2} \mathrm{NPs}$. (C) S. cerevisiae cells incubated with $1000 \mu \mathrm{g} \mathrm{mL}-1$ $\mathrm{Mg}(\mathrm{OH})_{2} \mathrm{NPs}$ showing the attachment of $\mathrm{Mg}(\mathrm{OH})_{2} \mathrm{NPs}$ to the outer cell surface.

We also confirmed these results by EDX of the treated S. cerevisiae cells, which showed the presence of $\mathrm{Mg}$ on the outer part of the cell membrane (Figure S6, ESI). Although the exposure of the S. cerevisiae cells to bare $\mathrm{Mg}(\mathrm{OH})_{2} \mathrm{NPs}$ at concentration $1000 \mu \mathrm{g} \mathrm{mL}-1$ caused a cytotoxicity effect (Figure $5 \mathrm{C}$ ), it did not cause an internalisation of $\mathrm{Mg}(\mathrm{OH})_{2} \mathrm{NPs}$, as the cell wall of $S$. cerevisiae cells is very thick $(200 \mathrm{~nm}$, Figure 5B) when compared to other microbial cells. We envisage two probable mechanisms for the antimicrobial effect of $\mathrm{Mg}(\mathrm{OH})_{2} \mathrm{NPs}$ on yeast. There is a significant accumulation of $\mathrm{Mg}(\mathrm{OH})_{2} \mathrm{NPs}$ on the cell membranes due to their cationic nature at neutral $\mathrm{pH}$. As these particles have very irregular morphology and they consist of smaller crystallites, their adhesion to the cell membrane in large amounts can potentially cause its dislocation and cracking. Local damage of the membrane may lead to cell viability loss although we do not observe a straight permeation of $\mathrm{Mg}(\mathrm{OH})_{2} \mathrm{NPs}$ to the S.cerevisiae wall. Another possible mechanism of membrane damage can be caused by the counter-ion atmosphere of the $\mathrm{Mg}(\mathrm{OH})_{2} \mathrm{NPs}$, which consists of highly concentrated hydroxyl ions $\left(\mathrm{OH}^{-}\right)$of very high local $\mathrm{pH}$ which can cause lipid hydrolysis on the membrane surface and killing the cell. Some of these mechanisms have been commented on by other authors for uncoated $\mathrm{Mg}(\mathrm{OH})_{2} \mathrm{NPs}[17,24,28]$.

We also examined the antimicrobial activity of $\mathrm{Mg}(\mathrm{OH})_{2} \mathrm{NPs}$ towards $C$. reinhardtii under similar conditions for various exposure times, as shown in Figure 4B. At a 10 min exposure time, all of the C. reinhardtii were viable at the similar level as the untreated sample. After two hours of incubation, the C. reinhardtii viability declined for $\mathrm{Mg}(\mathrm{OH})_{2} \mathrm{NPs}$ concentrations from $250 \mu \mathrm{g} \mathrm{mL} \mathrm{L}^{-1}$ to $1000 \mu \mathrm{g}$ 
$\mathrm{mL}^{-1}$. After $4 \mathrm{~h}$, the $C$. reinhardtii viability was reduced to $40 \%$ at $1000 \mu \mathrm{g} \mathrm{mL} \mathrm{m}^{-1}$ of $\mathrm{Mg}(\mathrm{OH})_{2} \mathrm{NPs}$, while, after $6 \mathrm{~h}$, it sharply declined for $250 \mu \mathrm{g} \mathrm{mL} \mathrm{m}^{-1}$ to $1000 \mu \mathrm{g} \mathrm{mL}{ }^{-1}$ concentrations of $\mathrm{Mg}(\mathrm{OH})_{2} \mathrm{NPs}$, which led to the complete loss of cell viability at concentrations above $750 \mu \mathrm{g} \mathrm{mL}{ }^{-1} \mathrm{Mg}(\mathrm{OH})_{2} \mathrm{NPs}$. Figure 6 shows TEM images of $C$. reinhardtii exposed to $\mathrm{Mg}(\mathrm{OH})_{2} \mathrm{NPs}$ at various concentrations. TEM images of the $C$. reinhardtii after $6 \mathrm{~h}$ of incubation with $\mathrm{Mg}(\mathrm{OH})_{2} \mathrm{NPs}$ indicate the localization of the $\mathrm{Mg}(\mathrm{OH})_{2} \mathrm{NPs}$ with respect to the cell membrane. One can see that the outer cell wall of $C$. reinhardtii obtained a thick layer of associated NPs after treatment with $750 \mu \mathrm{g} \mathrm{mL}^{-1}, 1000 \mu \mathrm{g} \mathrm{mL}$ and $5000 \mu \mathrm{g} \mathrm{mL}^{-1}$ concentrations of $\mathrm{Mg}(\mathrm{OH})_{2} \mathrm{NPs}$ (Figure $6 \mathrm{C}-\mathrm{F}$ ). The internalization of $\mathrm{Mg}(\mathrm{OH})_{2} \mathrm{NPs}$ in the $C$. reinhardtii was not observed, even at $5000 \mu \mathrm{g} \mathrm{mL}{ }^{-1} \mathrm{Mg}(\mathrm{OH})_{2} \mathrm{NPs}$, as shown in Figures $\mathrm{S} 7$ and S8. The EDX shows the absence of $\mathrm{Mg}$ in the inside of $C$. reinhardtii, but confirms its presence on the outer wall.
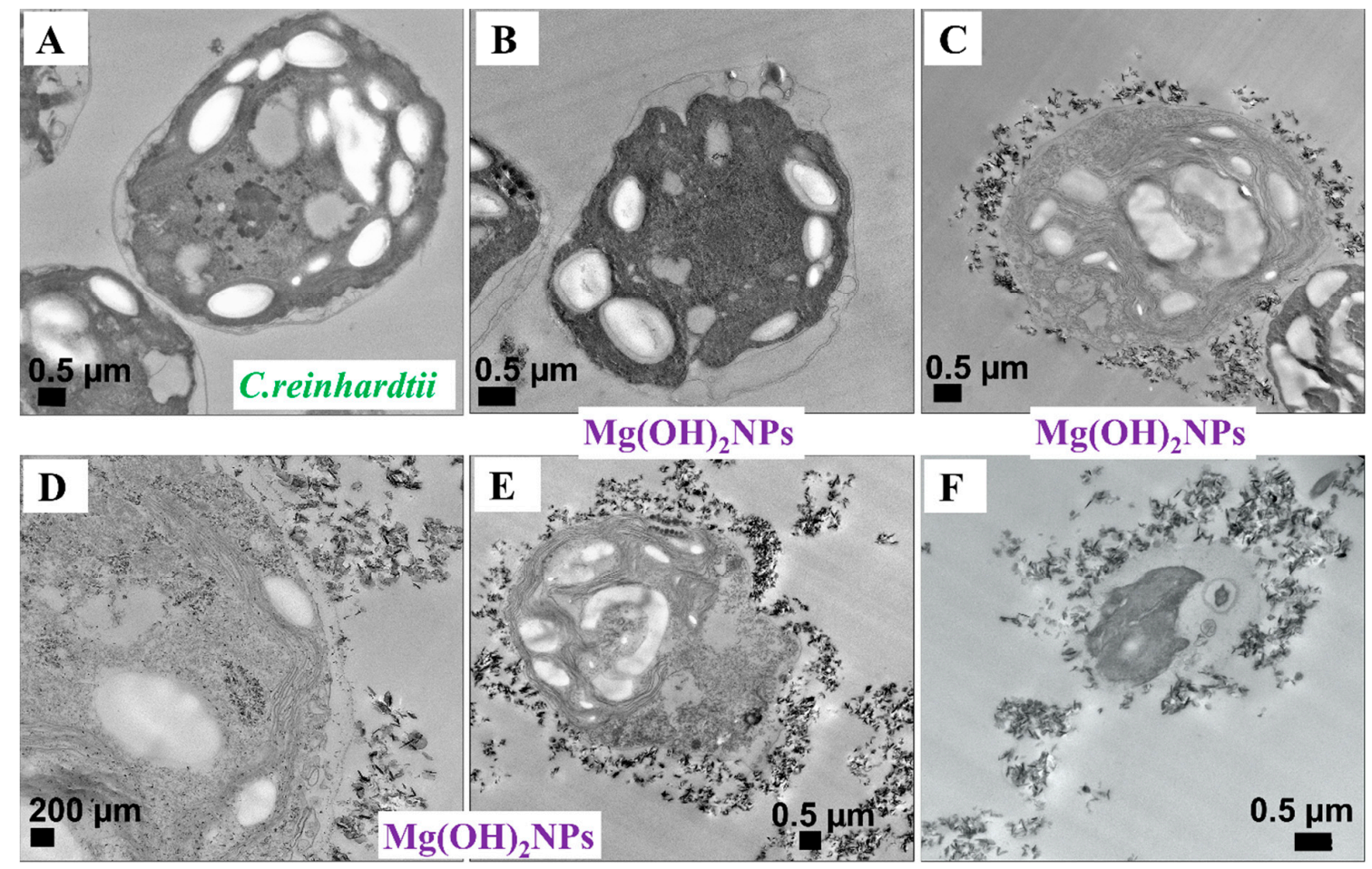

Figure 6. TEM images of $C$. reinhardtii after being exposed to $0,250,750,1000$ and $5000 \mu \mathrm{gL}^{-1}$ $\mathrm{Mg}(\mathrm{OH})_{2} \mathrm{NPs}$ for six hours (fixed, embedded in resin and sectioned). (A) An untreated sample without $\mathrm{Mg}(\mathrm{OH})_{2} \mathrm{NPs}$; (B) C. reinhardtii treated with $250 \mu \mathrm{g} \mathrm{mL}-1 \mathrm{Mg}(\mathrm{OH})_{2} \mathrm{NPs}$; (C) and (D) C. reinhardtii incubated with $750 \mu \mathrm{g} \mathrm{mL} \mathrm{m}^{-1} \mathrm{Mg}(\mathrm{OH})_{2} \mathrm{NPs}$ at different magnifications. (E) and (F) C. reinhardtii treated with $1000 \mu \mathrm{g} \mathrm{mL} \mathrm{L}^{-1}$ and $5000 \mu \mathrm{g} \mathrm{mL}^{-1} \mathrm{Mg}(\mathrm{OH})_{2} \mathrm{NPs}$, respectively.

Figure $4 \mathrm{C}$ shows the results for the effect of bare $\mathrm{Mg}(\mathrm{OH})_{2} \mathrm{NPs}$ towards $\mathrm{E}$. coli at various incubation times. The data demonstrate that the bare $\mathrm{Mg}(\mathrm{OH})_{2} \mathrm{NPs}$ have excellent antimicrobial effects on the $E$. coli at $6000 \mu \mathrm{g} \mathrm{mL} \mathrm{g}^{-1}$ for one day. The E. coli viability sharply decreases for treatment with $6000 \mu \mathrm{g} \mathrm{mL}^{-1}$ $\mathrm{Mg}(\mathrm{OH})_{2} \mathrm{NPs}$ after four hours of exposure. The viability decreases further after six hours and, after one day, it resulted in approximately $97 \%$ loss of viability. Past research suggested that the antibacterial effect might be credited to multiple factors: (i) the cellular internalization of NPs where they could potentially interfere with the bacterial DNA and cellular organelles [41-45]; (ii) immediate contacts with the bacterial cell wall [23,24]; and, (iii) the increased local dissolution of metal ions of the nanoscale metal oxide $[46,47]$. Usually, the antimicrobial impact is dependent on the size of the nanoparticles and a better antimicrobial effect is achieved with smaller nanoparticles $[17,48-50]$.

The $\mathrm{Mg}(\mathrm{OH})_{2} \mathrm{NPs}$ with the smallest size (about $70 \mathrm{~nm}$ ) had the highest antimicrobial activity. We undertook TEM imaging and EDX analysis to examine the location of magnesium in the E. coli 
after treating them with non-coated $\mathrm{Mg}(\mathrm{OH})_{2} \mathrm{NPs}$. Magnesium was not detected by the EDX in many randomly selected regions inside the E. coli, but it was primarily found on the outer side of the cell wall, as shown in Figure S9 (ESI). This showed that the dissolved magnesium ions and $\mathrm{Mg}(\mathrm{OH})_{2} \mathrm{NPs}$ did not go to the inside of E. coli. Nevertheless, evident changes of the E. coli cell structure were seen after incubation with $\mathrm{Mg}(\mathrm{OH})_{2} \mathrm{NPs}$. Figure 7D shows the images of untreated $E$. coli, where the bacteria have preserved the integrity of their cell walls. After incubation with $2500 \mu \mathrm{g} \mathrm{mL}^{-1}$ (7E) and $5000 \mu \mathrm{g}$ $\mathrm{mL}^{-1}(7 \mathrm{~F}) \mathrm{Mg}(\mathrm{OH})_{2} \mathrm{NPs}$ for one day, the cell profile became fussy and the walls of E. coli appear as disintegrated. Therefore, the antimicrobial activity of $\mathrm{Mg}(\mathrm{OH})_{2} \mathrm{NPs}$ might be expressed more via their adsorption on the outer side of the cell wall, rather than through internalization in the cell, which leads to the decay of the cell walls of E. coli. Furthermore, SEM imaging was used to study the presence of $\mathrm{Mg}(\mathrm{OH})_{2} \mathrm{NPs}$ on the surfaces of the bacteria. Figure 7A-C show E. coli samples after being treated with $2500 \mu \mathrm{g} \mathrm{mL}^{-1}$ and $5000 \mu \mathrm{g} \mathrm{mL} \mathrm{mg}^{-1} \mathrm{Mg}(\mathrm{OH})_{2} \mathrm{NPs}$ for one day. They indicate that the cell wall has a build-up of a dense layer of nanoparticles. Moreover, EDX indicated that the samples contain magnesium, and confirmed that the $\mathrm{Mg}(\mathrm{OH})_{2} \mathrm{NPs}$ have the ability to adhere on the bacterial cell wall with occasional penetration on the inside. Consequently, the E. coli lack of viability is associated with the compromised integrity of bacteria walls, which is seen by SEM and TEM for these samples. This is consistent with the mechanisms outlined above which indicates that the antimicrobial action of $\mathrm{Mg}(\mathrm{OH})_{2} \mathrm{NPs}$ on the cells is likely to be due to the cationic character of $\mathrm{Mg}(\mathrm{OH})_{2} \mathrm{NPs}$ that adsorb on the negatively charged bacterial cell wall by electrostatic attraction. The adsorbed $\mathrm{Mg}(\mathrm{OH})_{2} \mathrm{NPs}$ disrupt the integrity of the bacterial cell wall, which then increases its permeability and kills the bacteria.

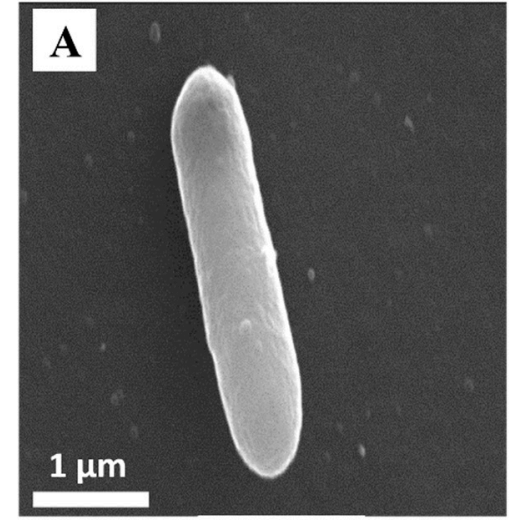

E.coli

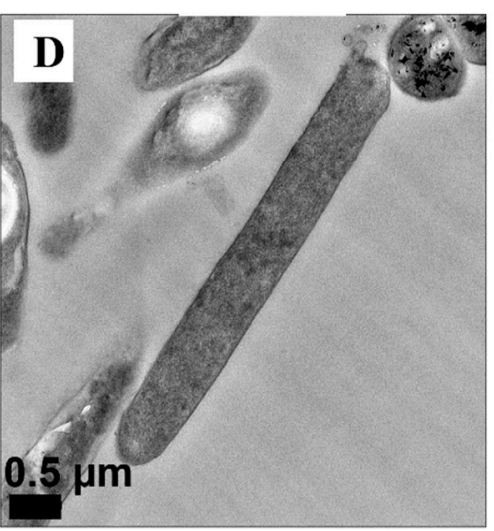

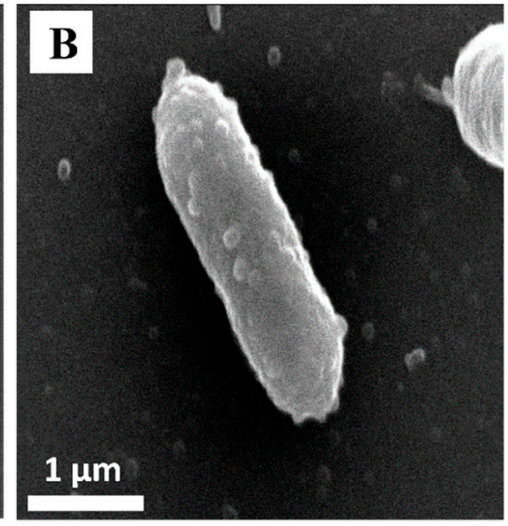

$2500 \mu \mathrm{g} \mathrm{mL} \mathrm{L}^{-1} \mathrm{Mg}(\mathrm{OH})_{2} \mathrm{NPs}$

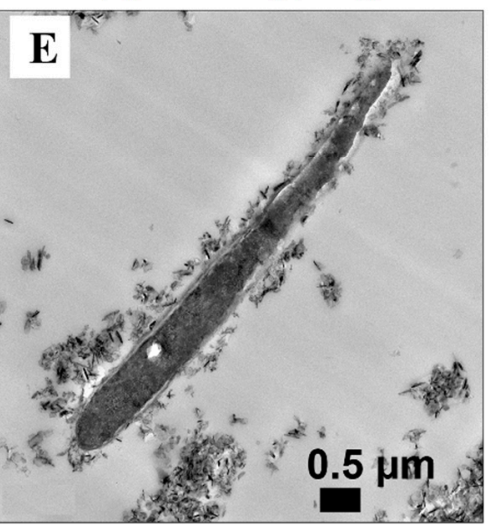

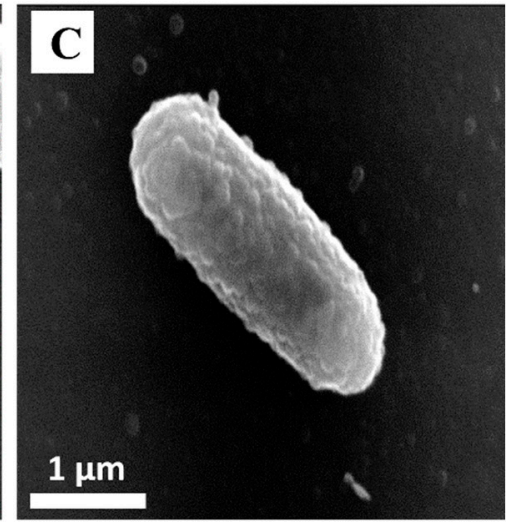

$5000 \mu \mathrm{g} \mathrm{mL}^{-1} \mathrm{Mg}(\mathrm{OH})_{2} \mathrm{NPs}$

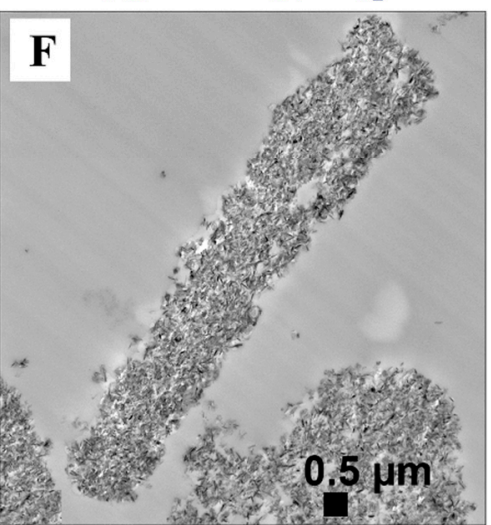

Figure 7. Scanning electron microscopy (SEM) and TEM images of E. coli after being incubated for $24 \mathrm{~h}$ with a suspension of bare $\mathrm{Mg}(\mathrm{OH})_{2} \mathrm{NPs}$ : (A) SEM and (D) TEM images of an untreated sample. (B) SEM and (E) TEM images of E. coli incubated with $2500 \mu \mathrm{g} \mathrm{mL} \mathrm{mL}^{-1} \mathrm{Mg}(\mathrm{OH})_{2} \mathrm{NPs}$. (C) SEM and (F) TEM images of $E$. coli incubated with $5000 \mu \mathrm{g} \mathrm{mL}{ }^{-1} \mathrm{Mg}(\mathrm{OH})_{2} \mathrm{NPs}$. 


\subsection{Zeta Potential Measurements of Cells after Treatment with $\mathrm{Mg}(\mathrm{OH})_{2} \mathrm{NPS}$}

We further explored the effect of the particles attachment on the outer cell wall, as it may play a significant role on their antimicrobial action $[17,24,28]$. We studied the zeta potential of the S.cerevisiae, C. reinhardtii, and E. coli after treatment with $\mathrm{Mg}(\mathrm{OH})_{2} \mathrm{NPs}$ in solution. The cells were incubated with $\mathrm{Mg}(\mathrm{OH})_{2} \mathrm{NPs}$ suspensions at different particle concentrations. Subsequently, an aliquot of every suspension was taken to examine the cells average zeta potential value by a Zetasizer instrument. We found that $\mathrm{Mg}(\mathrm{OH})_{2} \mathrm{NPs}$ have an average zeta potential of $+30 \pm 6 \mathrm{mV}$. Upon incubation with bare $\mathrm{Mg}(\mathrm{OH})_{2} \mathrm{NPs}$, the S.cerevisiae cells, which are negatively charged (zeta potential of $-12 \pm 5 \mathrm{mV}$ ), still were shown to be negative, but significantly reduced by magnitude zeta potential due to a build-up of cationic NPs, as shown in Figure 8A. Note that the zeta potential of threated cells does not vary much with the duration of the treatment.

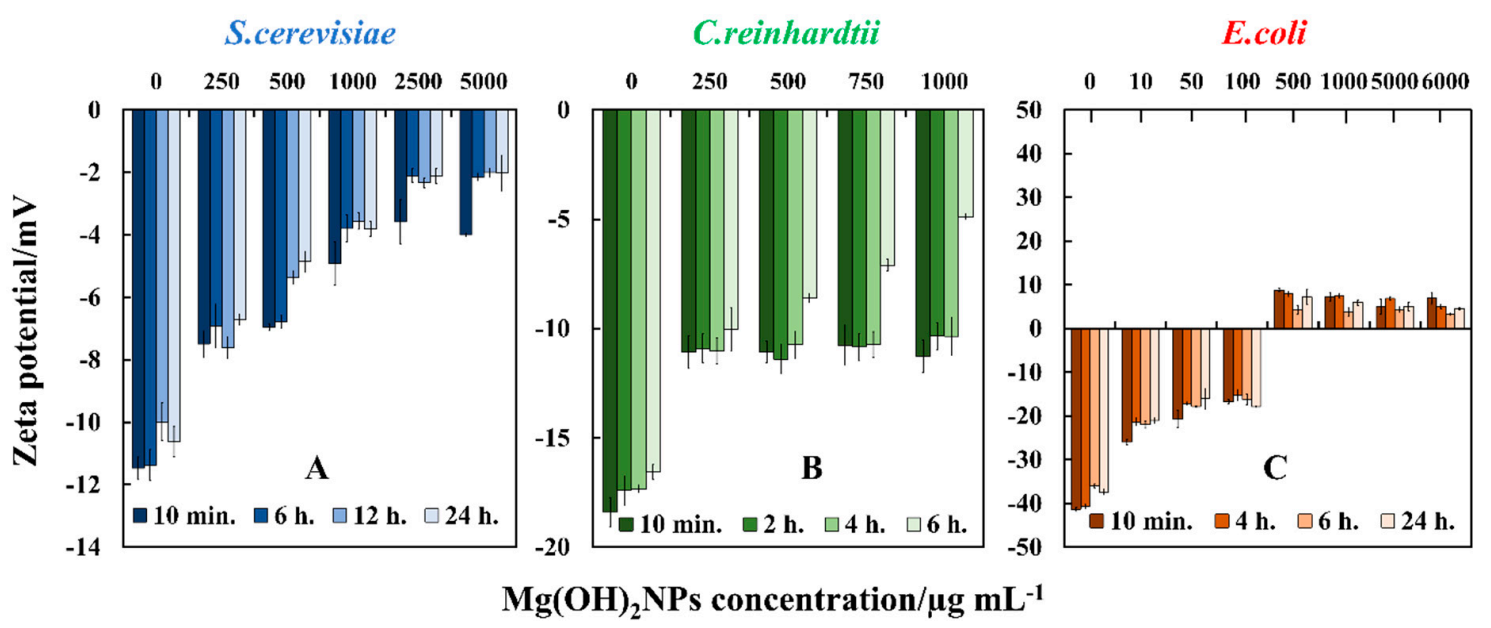

Figure 8. The zeta potential of cells treated with different concentrations of $\mathrm{Mg}(\mathrm{OH})_{2} \mathrm{NP}$ suspensions at various incubation times: (A) S.cerevisiae, (B) C. reinhardtii, and (C) E. coli cells.

The $C$. reinhardtii cells that have a negative zeta potential of $-18 \pm 5 \mathrm{mV}$ also reduced their zeta potential by magnitude after treatment with the cationic $\mathrm{Mg}(\mathrm{OH})_{2} \mathrm{NPs}$, but did not charge reverse, even at high particle concentrations, as presented in Figure 8B. Figure 8C shows the impact of bare $\mathrm{Mg}(\mathrm{OH})_{2} \mathrm{NPs}$ on the E. coli zeta potential. E. coli cells, which carried negative charge (zeta potential $-41 \pm 5 \mathrm{mV}$ ), remained negatively charged when treated with up to $100 \mu \mathrm{g} \mathrm{mL}-1 \mathrm{Mg}(\mathrm{OH})_{2} \mathrm{NPs}$. At higher $\mathrm{Mg}(\mathrm{OH})_{2} \mathrm{NPs}$ concentration, the zeta potential of $E$. coli cells turned positive when exposed to $500 \mu \mathrm{g} \mathrm{mL} \mathrm{L}^{-1}$ to $6000 \mu \mathrm{g} \mathrm{mL} \mathrm{m}^{-1} \mathrm{Mg}(\mathrm{OH})_{2} \mathrm{NPs}$. These results show that the adhesion of $\mathrm{Mg}(\mathrm{OH})_{2} \mathrm{NPs}$ to cells might indeed be primarily driven by electrostatic interactions [17,51]. It can be concluded that the positive charge of $\mathrm{Mg}(\mathrm{OH})_{2} \mathrm{NPs}$ has high impact on the adsorption of particles on the cells membrane. The SEM and TEM images confirmed this (Figure 6).

\subsection{Antimicrobial Assay of Polyelectrolyte-Coated $\mathrm{Mg}(\mathrm{OH})_{2} \mathrm{NPs}$ on S.cerevisiae, C. reinhardtii, and E. coli}

We studied the antimicrobial activity of $\mathrm{Mg}(\mathrm{OH})_{2} \mathrm{NPs}$ that were coated with multilayers of polyelectrolytes on S.cerevisiae, C. reinhardtii, and E. coli. We functionalized $\mathrm{Mg}(\mathrm{OH})_{2} \mathrm{NPs}$ with PSS and $\mathrm{PAH}$ and compared their antimicrobial effect with that of the bare $\mathrm{Mg}(\mathrm{OH})_{2} \mathrm{NPs}$. The aqueous suspensions of S.cerevisiae were incubated with $\mathrm{Mg}(\mathrm{OH})_{2} \mathrm{NPs} / \mathrm{PSS}$ and $\mathrm{Mg}(\mathrm{OH})_{2} \mathrm{NPs} / \mathrm{PSS} / \mathrm{PAH}$ suspensions at various particle concentrations $\left(0,250,500,1000,2500\right.$, and $\left.5000 \mu \mathrm{g} \mathrm{mL}^{-1}\right)$ for up to one day. The results represented in Figure $9 \mathrm{~A}$ show that the anionic $\mathrm{Mg}(\mathrm{OH})_{2} \mathrm{NPs} / \mathrm{PSS}$ have a lower antimicrobial activity on S.cerevisiae when compared to the cationic bare $\mathrm{Mg}(\mathrm{OH})_{2} \mathrm{NPs}$ (c.f. Figure $4 \mathrm{~A})$. No change in the S.cerevisiae viability was registered for $\mathrm{Mg}(\mathrm{OH})_{2} \mathrm{NPs} / \mathrm{PSS}$, even at high particle concentrations, at incubating times up to six hours. The same treatment with the cationic $\mathrm{Mg}(\mathrm{OH})_{2} \mathrm{NPs} / \mathrm{PSS} / \mathrm{PAH}$ showed a significant antimicrobial activity on S.cerevisiae at particle 
concentrations of 1000,2500 , and $5000 \mu \mathrm{g} \mathrm{mL}^{-1}$, as shown in Figure 9B. A very strong effect of the $\mathrm{Mg}(\mathrm{OH})_{2} \mathrm{NPs} / \mathrm{PSS} / \mathrm{PAH}$ on S.cerevisiae viability was observed upon their incubation with high particle concentrations of $5000 \mu \mathrm{g} \mathrm{mL} \mathrm{L}^{-1}$ for up to $24 \mathrm{~h}$. In contrast, upon incubation with the anionic $\mathrm{Mg}(\mathrm{OH})_{2} \mathrm{NPs} / \mathrm{PSS}$ at high particle concentrations of $5000 \mu \mathrm{g} \mathrm{mL}-1$, we observed a moderate impact on S.cerevisiae viability for up to one day of incubation (Figure 9A). Figure S12 compares the anti-yeast activity bare $\mathrm{Mg}(\mathrm{OH})_{2} \mathrm{NPs}$ with $\mathrm{Mg}(\mathrm{OH})_{2} \mathrm{NPs} / \mathrm{PSS}$ and $\mathrm{Mg}(\mathrm{OH})_{2} \mathrm{NPs} / \mathrm{PSS} / \mathrm{PAH}$ as a function of the nanoparticle concentration for $24 \mathrm{~h}$ of exposure.

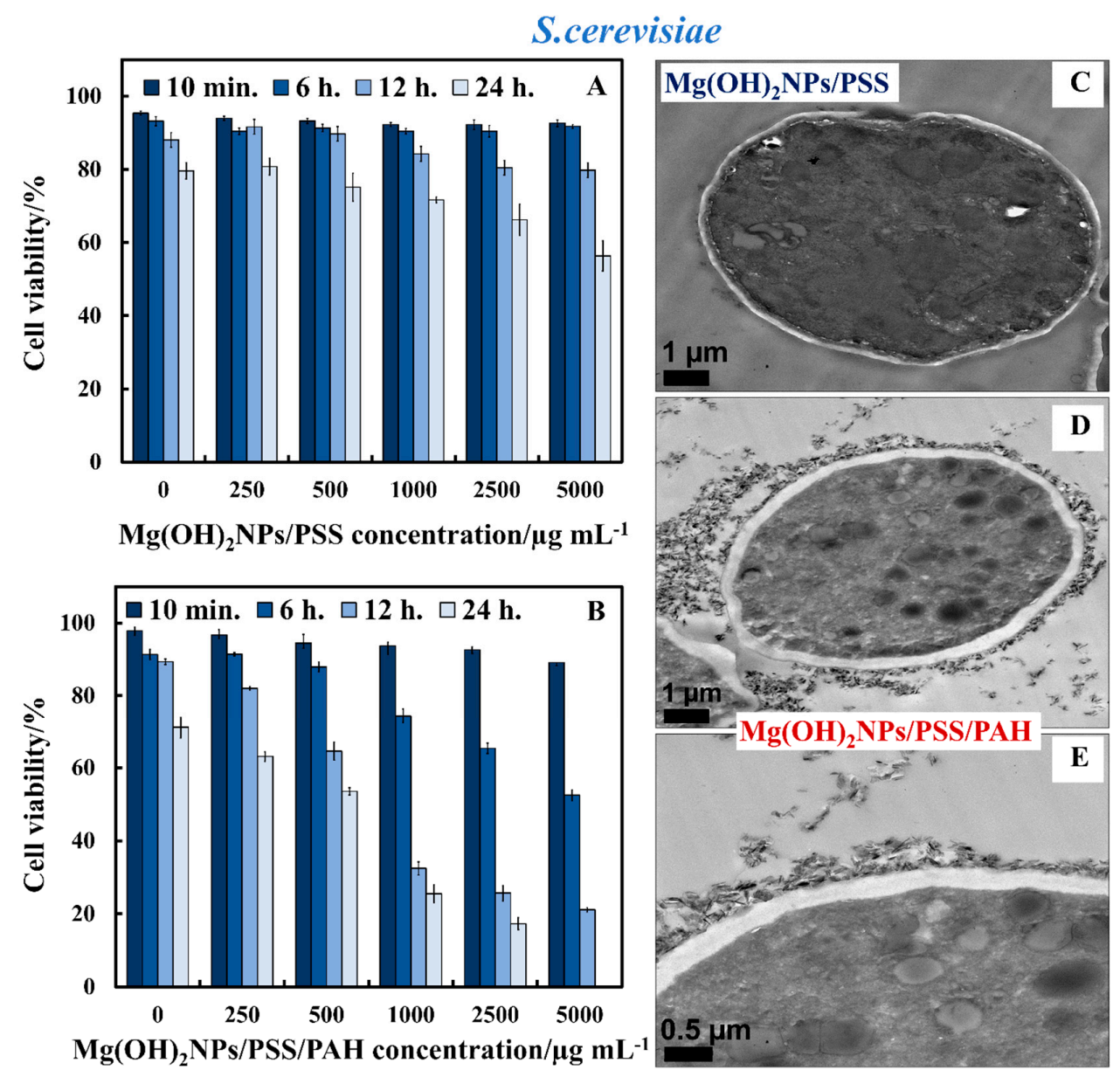

Figure 9. S. cerevisiae cell viability as a function of nanoparticle concentration after incubation for up to 24 $\mathrm{h}$ with $(\mathbf{A}) \mathrm{Mg}(\mathrm{OH})_{2} \mathrm{NPs} / \mathrm{PSS}$ and $(\mathbf{B}) \mathrm{Mg}(\mathrm{OH})_{2} \mathrm{NPs} / \mathrm{PSS} / \mathrm{PAH}$. TEM images of $S$. cerevisiae cells incubated for $24 \mathrm{~h}$ with $(\mathbf{C}) \mathrm{Mg}(\mathrm{OH})_{2} \mathrm{NPs} / \mathrm{PSS}$ and $(\mathbf{D}, \mathbf{E}) \mathrm{Mg}(\mathrm{OH})_{2} \mathrm{NPs} / \mathrm{PSS} / \mathrm{PAH}$ at different magnifications.

Hence, by coating the $\mathrm{Mg}(\mathrm{OH})_{2} \mathrm{NPs}$ with an outer layer of anionic polyelectrolyte, their antimicrobial activity is significantly decreased because of the electrostatic repulsion between the anionic $\mathrm{Mg}(\mathrm{OH})_{2} \mathrm{NPs} / \mathrm{PSS}$ and the anionic surface of S. cerevisiae cells. Figure 9C-E show TEM images of $S$. cerevisiae cells after their incubation with $\mathrm{Mg}(\mathrm{OH})_{2} \mathrm{NPs}$ that were coated with PSS and PAH layers.

The TEM image in Figure $9 \mathrm{C}$ indirectly confirms the lack of nanoparticle accumulation due to the electrostatic repulsion among the anionic $\mathrm{Mg}(\mathrm{OH})_{2} \mathrm{NPs} / \mathrm{PSS}$ and the negatively charged S. cerevisiae cell wall. Figure 9D,E show the great accumulation of $\mathrm{Mg}(\mathrm{OH})_{2} \mathrm{NPs} / \mathrm{PSS} / \mathrm{PAH}$ on the cell walls, which corresponds to a much higher activity towards $S$. cerevisiae. One can conclude that coating $\mathrm{Mg}(\mathrm{OH})_{2} \mathrm{NPs}$ with PSS as an external layer significantly diminishes their ability to attach on the treated cells, as shown in Figure 9C. S. cerevisiae cell viability tests revealed that $\mathrm{Mg}(\mathrm{OH})_{2} \mathrm{NPs} / \mathrm{PSS}$ were much less effective in killing the cells than the $\mathrm{Mg}(\mathrm{OH})_{2} \mathrm{NPs} / \mathrm{PSS} / \mathrm{PAH}$ or bare $\mathrm{Mg}(\mathrm{OH})_{2} \mathrm{NPs}$, which strongly accumulate on the cell membrane due to electrostatic attraction. These results were 
also supported by the TEM images of S. cerevisiae. Figure S16 shows the same data as Figure 9A,B in $\mathrm{CFU} \mathrm{ml}{ }^{-1}$. Figure $10 \mathrm{~A}, \mathrm{~B}$ compares the antimicrobial activity of multilayer-coated $\mathrm{Mg}(\mathrm{OH})_{2} \mathrm{NPs}$ with PSS and PAH polyelectrolytes at various NPs concentrations on the C. reinhardtii. Figure 10A shows that, for incubating times of up to $6 \mathrm{~h}$, no measurable variation in the $C$. reinhardtii cell viability was detected for $\mathrm{Mg}(\mathrm{OH})_{2} \mathrm{NPs} / \mathrm{PSS}$, even at high particle concentrations. However, at similar conditions, the cationic $\mathrm{Mg}(\mathrm{OH})_{2} \mathrm{NPs} / \mathrm{PSS} / \mathrm{PAH}$ displayed a marked antimicrobial activity on $C$. reinhardtii, even at $250 \mu \mathrm{g} \mathrm{mL}{ }^{-1}$. A very strong effect of the $\mathrm{Mg}(\mathrm{OH})_{2} \mathrm{NPs} / \mathrm{PSS} / \mathrm{PAH}$ on the $C$. reinhardtii cells viability was observed for exposure times of up to six hours at $1000 \mu \mathrm{g} \mathrm{mL}^{-1}$ particle concentrations (Figure 10B). One can conclude that, by coating the $\mathrm{Mg}(\mathrm{OH})_{2} \mathrm{NPs}$ with an external layer of anionic polyelectrolyte, their antimicrobial activity decreased for both $S$. cerevisiae and C. reinhardtii, because of the electrostatic repulsion between the $\mathrm{Mg}(\mathrm{OH})_{2} \mathrm{NPs} / \mathrm{PSS}$ and the cells walls. Figure 10C-E confirm this hypothesis with TEM images of $C$. reinhardtii exposed into the polyelectrolyte-coated $\mathrm{Mg}(\mathrm{OH})_{2} \mathrm{NPs}$. We also conducted similar tests with Gram-negative bacteria (E. coli) and polyelectrolyte-coated $\mathrm{Mg}(\mathrm{OH})_{2} \mathrm{NPs}$ when the bacterial cells were removed from their culture media. Figure S17 (ESI) shows the same data as Figure $10 \mathrm{~A}, \mathrm{~B}$ in $\mathrm{CFU} \mathrm{mL} \mathrm{m}^{-1}$. Figure $\mathrm{S} 13$ compares the anti-yeast activity bare $\mathrm{Mg}(\mathrm{OH})_{2} \mathrm{NPs}$ with $\mathrm{Mg}(\mathrm{OH})_{2} \mathrm{NPs} / \mathrm{PSS}$ and $\mathrm{Mg}(\mathrm{OH})_{2} \mathrm{NPs} / \mathrm{PSS} / \mathrm{PAH}$ as a function of the nanoparticle concentration for $24 \mathrm{~h}$ of exposure.

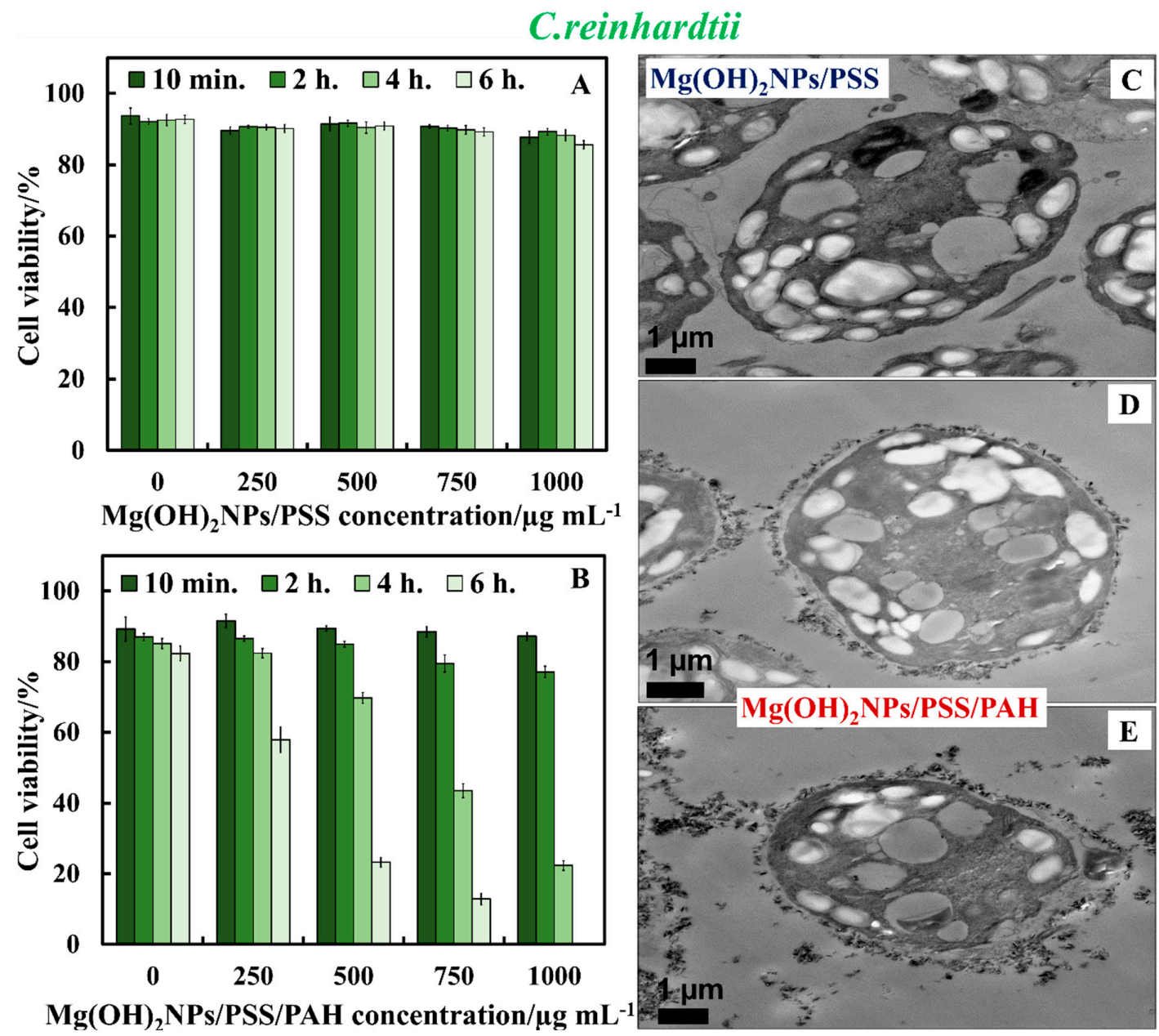

Figure 10. C. reinhardtii cell viability as a function of nanoparticle concentration after incubation for up to $6 \mathrm{~h}$ with (A) $\mathrm{Mg}(\mathrm{OH})_{2} \mathrm{NPs} / \mathrm{PSS}$ and (B) $\mathrm{Mg}(\mathrm{OH})_{2} \mathrm{NPs} / \mathrm{PSS} / \mathrm{PAH}$. TEM images of $C$. reinhardtii after being incubated for $6 \mathrm{~h}$ with (C) $1000 \mu \mathrm{g} \mathrm{mL} \mathrm{mg}^{-1} \mathrm{Mg}(\mathrm{OH})_{2} \mathrm{NPs} / \mathrm{PSS}$, (D) $750 \mu \mathrm{g} \mathrm{mL} \mathrm{mg}^{-1} \mathrm{Mg}(\mathrm{OH})_{2} \mathrm{NPs}$ /PSS/PAH, and (E) $1000 \mu \mathrm{g} \mathrm{mL} \mathrm{L}^{-1}$ of $\mathrm{Mg}(\mathrm{OH})_{2} \mathrm{NPs} / \mathrm{PSS} / \mathrm{PAH}$. 
Figure 11A,B show the effect of polyelectrolyte multilayer-coated $\mathrm{Mg}(\mathrm{OH})_{2} \mathrm{NPs}$ against E. coli. Similarly to $S$. cerevisiae and $C$. reinhardtii, we found no pronounced antibacterial effect of $\mathrm{Mg}(\mathrm{OH})_{2} \mathrm{NPs} / \mathrm{PSS}$ on $E$. coli for various exposure times. Figure $11 \mathrm{~A}$ shows that the antibacterial activity of $\mathrm{Mg}(\mathrm{OH})_{2} \mathrm{NPs} / \mathrm{PSS}$ against $E$. coli is also much lower than the one of the bare $\mathrm{Mg}(\mathrm{OH})_{2} \mathrm{NPs}$. We envisage that this result is due to a similar decrease of the NPs accumulation on the bacterial cell wall after the functionalization of the $\mathrm{Mg}(\mathrm{OH})_{2} \mathrm{NPs}$ with an anionic PSS layer (see Figure $11 \mathrm{C}, \mathrm{D}, \mathrm{F}, \mathrm{G}$ ). The subsequent deposition of a cationic polyelectrolyte layer of $\mathrm{PAH}$, yields $\mathrm{Mg}(\mathrm{OH})_{2} \mathrm{NPs} / \mathrm{PSS} / \mathrm{PAH}$, which showed excellent antibacterial properties against E. coli, as seen in Figure 11B. Note that the PAH-coated NPs have even stronger antibacterial activity than the uncoated $\mathrm{Mg}(\mathrm{OH})_{2} \mathrm{NPs}$ towards $E$. coli. Hence, the antibacterial activity of the polyelectrolyte coated $\mathrm{Mg}(\mathrm{OH})_{2} \mathrm{NPs}$ appears to alternate with their surface charge. Figure S18 (ESI) shows the same data as in Figure 10A,B in CFU mL ${ }^{-1}$.

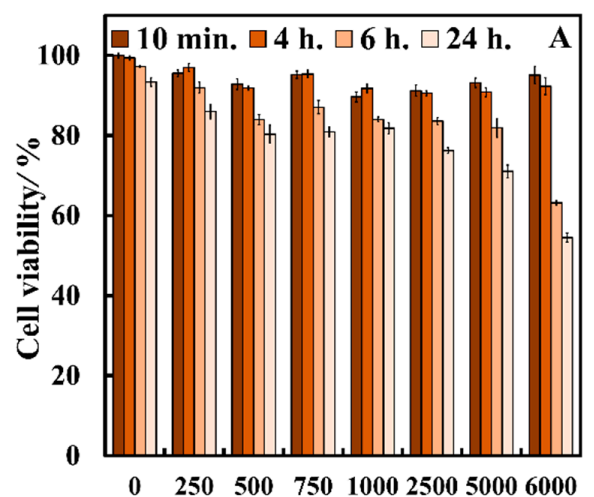
$\mathrm{Mg}(\mathrm{OH})_{2} \mathrm{NPs} / \mathrm{PSS}$ concentration $/ \mu \mathrm{g} \mathrm{mL}$

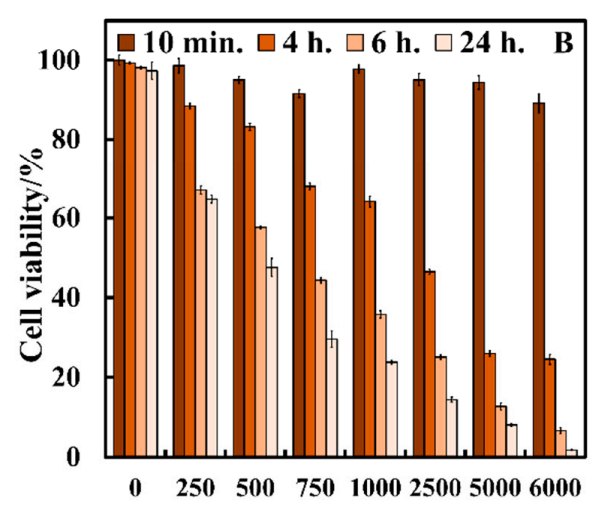

$\mathrm{Mg}(\mathrm{OH})_{2} \mathrm{NPs} / \mathrm{PSS} / \mathrm{PAH}$ concentration $/ \mu \mathrm{g} \mathrm{mL}^{-1}$

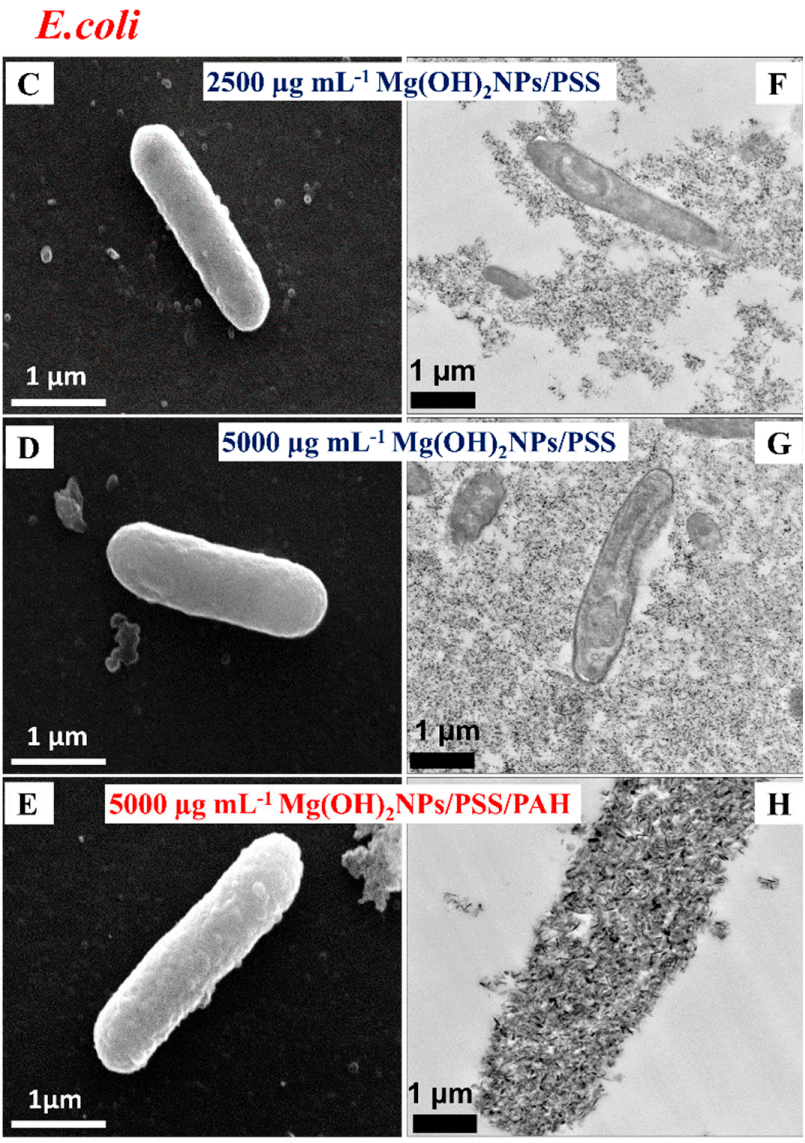

Figure 11. The E. coli cell viability after treatment with $(\mathbf{A}) \mathrm{Mg}(\mathrm{OH})_{2} \mathrm{NPs} / \mathrm{PSS}$ and $(\mathbf{B}) \mathrm{Mg}(\mathrm{OH})_{2} \mathrm{NPs} / \mathrm{PSS} /$ PAH for various incubation times as a function of the NPs concentration. (C) SEM and (F) TEM images of E. coli after incubation with $2500 \mu \mathrm{g} \mathrm{mL} \mathrm{m}^{-1} \mathrm{Mg}(\mathrm{OH})_{2} \mathrm{NPs} / \mathrm{PSS}$; (D) SEM and (G) TEM images of E. coli after incubation with $5000 \mu \mathrm{g} \mathrm{mL} \mathrm{mL}^{-1} \mathrm{Mg}(\mathrm{OH})_{2} \mathrm{NPs} / \mathrm{PSS}$; (E) SEM and (H) TEM images of E. coli after incubation with $5000 \mu \mathrm{g} \mathrm{mL} \mathrm{L}^{-1} \mathrm{Mg}(\mathrm{OH})_{2} \mathrm{NPs} / \mathrm{PSS} / \mathrm{PAH}$. The cells were removed from the particle suspension before the sample preparation for TEM and SEM imaging.

The E. coli Gram-negative cell wall is composed of an organized triple membrane that contains a thin inner layer of peptidoglycan between an outer membrane consisting of porins [41], phospholipids molecules, lipopolysaccharides (LPS), lipoproteins, surface proteins, and a cytoplasmic membrane consisting of phospholipids molecules and porins (see Figure S10) [41]. Figure 11C-H show the SEM and TEM images of $E$. coli after treatment for $24 \mathrm{~h}$ with $\mathrm{Mg}(\mathrm{OH})_{2} \mathrm{NPs}$ coated with a single layer of PSS and ones with additional layer of PAH. Note that there are a very few $\mathrm{Mg}(\mathrm{OH})_{2} \mathrm{NPs} / \mathrm{PSS}$ that are attached to the bacteria, as shown in Figure 11C,D,F,G. On the other hand, we found a significant accumulation 
of $\mathrm{Mg}(\mathrm{OH})_{2} \mathrm{NPs} / \mathrm{PSS} / \mathrm{PAH}$ onto the surface of the bacteria, as shown in Figure 11E,H. These SEM and TEM images are consistent with the antibacterial activity profile of the polyelectrolyte-coated $\mathrm{Mg}(\mathrm{OH})_{2} \mathrm{NPs}$ against $E$. coli, as reported in Figure 11B. It can be argued that the weak attachment of the anionic particles $\mathrm{Mg}(\mathrm{OH})_{2} \mathrm{NPs} / \mathrm{PSS}$ to the bacteria, as supported via the SEM and TEM images, causes little damage of the bacteria wall. Figure $7 \mathrm{~B}, \mathrm{C}, \mathrm{E}, \mathrm{F}$ for the bare $\mathrm{Mg}(\mathrm{OH})_{2} \mathrm{NPs}$ and Figure $11 \mathrm{E}, \mathrm{H}$ for the $\mathrm{Mg}(\mathrm{OH})_{2} \mathrm{NPs} / \mathrm{PSS} / \mathrm{PAH}$, show that there is a substantial build-up of cationic NPs (uncoated and $\mathrm{PAH}$-coated $\mathrm{Mg}(\mathrm{OH})_{2} \mathrm{NPs}$ ) onto the anionic bacterial cell surface, which corresponds to a greater local increase of the NPs concentration that successively disrupts the bacteria. Figure S14 compares the anti-yeast activity bare $\mathrm{Mg}(\mathrm{OH})_{2} \mathrm{NPs}$ with $\mathrm{Mg}(\mathrm{OH})_{2} \mathrm{NPs} / \mathrm{PSS}$ and $\mathrm{Mg}(\mathrm{OH})_{2} \mathrm{NPs} / \mathrm{PSS} / \mathrm{PAH}$ as a function of the nanoparticle concentration for $24 \mathrm{~h}$ of exposure. We also examined the antibacterial activity of $\mathrm{MgCl}_{2}$ solutions of various concentrations for $24 \mathrm{~h}$ on $\mathrm{E}$. coli in order to investigate if this is due to higher local concentration of $\mathrm{Mg}^{2+}$ ions, where the bacterial cells were extracted from the culture media in a similar processes, as explained above for the $\mathrm{Mg}(\mathrm{OH})_{2} \mathrm{NPs}$ treatment with $E$. coli. We found that $\mathrm{MgCl}_{2}$ did not have significant antibacterial action when compared to the $\mathrm{Mg}(\mathrm{OH})_{2} \mathrm{NPs}$, even at high concentrations, as shown in Figure S11 (ESI). The effect of the $\mathrm{pH}$ on the bacterial cell viability is similar-we found that the incubation of bacteria with $\mathrm{NaOH}$ solution of $\mathrm{pH} 10.4$ (corresponding to the $\mathrm{pH}$ of bare $\mathrm{Mg}(\mathrm{OH})_{2} \mathrm{NPs}$ suspension) did not produce a comparable effect. Hence, the analysis of these results suggests that magnesium ions in the $\mathrm{Mg}(\mathrm{OH})_{2} \mathrm{NPs}$ and the basic $\mathrm{pH}$ of 10.4 is unlikely to be responsible for the killing of E. coli [28]. The most likely explanation is the rough surface morphology of the clustered $\mathrm{Mg}(\mathrm{OH})_{2} \mathrm{NPs}$, which, when electrostatically attracted towards the cell membrane, cause membrane disruptions that kill the bacteria.

Note that neither $\mathrm{Mg}^{2+}$ ions nor reactive oxygen species (ROS) generation can explain the antimicrobial properties of the $\mathrm{Mg}(\mathrm{OH})_{2} \mathrm{NPs}$. The solubility of $\mathrm{Mg}(\mathrm{OH})_{2} \mathrm{NPs}$ is too low for the free $\mathrm{Mg}^{2+}$ ions to have any measurable cytotoxic effect, as their concentration is limited by the solubility product of $\mathrm{Mg}(\mathrm{OH})_{2} \mathrm{NPs}\left(1.8 \times 10^{-11} \mathrm{M}^{3}\right)$. The $\mathrm{Mg}(\mathrm{OH})_{2} \mathrm{NPs}$ are not a photoactive material, which means that it is not producing ROS upon illumination. Hence, the antimicrobial effect is likely coming from the surface roughness of the $\mathrm{Mg}(\mathrm{OH})_{2} \mathrm{NPs}$, which electrostatically stick onto the negatively charged microbial cells due to their cationic character and pierce their cell membrane. The effect is also amplified by the high concentration of $\mathrm{OH}$ - ions in their electric double layers, which they bring in close contact with the microbial cell surface upon adhesion. This can potentially lead to partial hydrolysis of the lipids in their cell membranes and cell death.

We also determined the MIC of free $\mathrm{Mg}(\mathrm{OH})_{2} \mathrm{NPs}$ and PAH-coated $\mathrm{Mg}(\mathrm{OH})_{2} \mathrm{NPs}$ on E. coli, S. cerevisiae, and C. reinhardtii. We found that, at the same conditions, the MIC of the PAH-coated $\mathrm{Mg}(\mathrm{OH})_{2} \mathrm{NPs}$ is two times lower than that of free $\mathrm{Mg}(\mathrm{OH})_{2} \mathrm{NPs}$ (see Table 1).

Table 1. Minimum inhibitory concentration (MIC) of bare $\mathrm{Mg}(\mathrm{OH})_{2} \mathrm{NPs}$ and PSS/PAH-coated $\mathrm{Mg}(\mathrm{OH})_{2} \mathrm{NPs}$ against $C$. reinhardtii, S. cerevisiae and E. coli.

\begin{tabular}{ccc}
\hline & $\mathbf{M g}(\mathbf{O H})_{2} \mathbf{N P s}$ & PSS/PAH-coated $\mathbf{M g}(\mathbf{O H})_{2} \mathbf{N P s}$ \\
\cline { 2 - 3 } & $\mathbf{M I C}$ & $\mathbf{M I C}$ \\
\hline C. reinhardtii & $1000 \mu \mathrm{g} \mathrm{mL}^{-1}$ & $750 \mu \mathrm{g} \mathrm{mL}^{-1}$ \\
S.cerevisiae & $5000 \mu \mathrm{g} \mathrm{mL}^{-1}$ & $2500 \mu \mathrm{g} \mathrm{mL}^{-1}$ \\
E. coli & $5000 \mu \mathrm{g} \mathrm{mL}^{-1}$ & $2500 \mu \mathrm{gL} \mathrm{mL}^{-1}$ \\
\hline
\end{tabular}

\subsection{Effect of the bare $\mathrm{Mg}(\mathrm{OH})_{2} \mathrm{NPs}$ and PSS/PAH-coated $\mathrm{Mg}(\mathrm{OH})_{2} \mathrm{NPs}$ on human cells}

Figure $\mathrm{S} 19$ (ESI) shows the cytotoxicity assay of the bare $\mathrm{Mg}(\mathrm{OH})_{2} \mathrm{NPs}$ and $\mathrm{Mg}(\mathrm{OH})_{2} \mathrm{NPs} / \mathrm{PSS} / \mathrm{PAH}$ on human embryonic kidney cells (HEK 293 cell line) for up to $24 \mathrm{~h}$ of exposure. The cells were removed from the original culture media and then transferred to PBS before exposure to the nanoparticles. This was done to avoid the adsorption of the media components on the particles. Both runs were done at the varying overall nanoparticles concentration and at different incubation times. One can see a very 
small effect on the presence of free $\mathrm{Mg}(\mathrm{OH})_{2} \mathrm{NPs}$ and $\mathrm{Mg}(\mathrm{OH})_{2} \mathrm{NPs} / \mathrm{PSS} / \mathrm{PAH}$ on the cells viability over a period of up to $24 \mathrm{~h}$. Note that the control sample of HEK 293 cells has lost a minor fraction of their viability over this period of time due to the removal of the culture media. One can conclude that the nanoparticle does not measurably impact the HEK 292 cell viability up to $2500 \mu \mathrm{gL}^{-1}$. However, the effect on yeast, algae, and $E$. coli is very significant at these concentrations of free $\mathrm{Mg}(\mathrm{OH})_{2} \mathrm{NPs}$ and $\mathrm{Mg}(\mathrm{OH})_{2} \mathrm{NPs} / \mathrm{PSS} / \mathrm{PAH}$ - see Figures 4, 9B, 10B and 11B, respectively. Therefore, one may conclude that the $\mathrm{Mg}(\mathrm{OH})_{2} \mathrm{NPs}$ show excellent biocompatibility with this human cell line. More research will be conducted in the future regarding the effects of the nanoparticles on different type of other cell lines.

\section{Conclusions}

When compared with other inorganic nanoparticles that were studied in the literature, $\mathrm{Mg}(\mathrm{OH})_{2} \mathrm{NPs}$ have high antimicrobial activity at moderate to high particle concentrations. However, the $\mathrm{Mg}(\mathrm{OH})_{2} \mathrm{NPs}$ have great application potential as a new antimicrobial agent, since $\mathrm{Mg}(\mathrm{OH})_{2}$ is a nontoxic material and has been broadly used in medical industries and food. Here, we studied various ways to control the antimicrobial activity and cytotoxicity of a range of bare and surface-modified $\mathrm{Mg}(\mathrm{OH})_{2} \mathrm{NPs}$ on three different types of microbial cells: microalgae, yeast, and bacteria. The antimicrobial activity of the $\mathrm{Mg}(\mathrm{OH})_{2} \mathrm{NPs}$ on S. cerevisiae, C. reinhardtii, and E. coli was examined. This work suggests that bare $\mathrm{Mg}(\mathrm{OH})_{2} \mathrm{NPs}$ are effective antimicrobial agents. The results from TEM and SEM analysis showed that the direct contact between the $\mathrm{Mg}(\mathrm{OH})_{2} \mathrm{NPs}$ and the cell membrane of $S$. cerevisiae, $C$. reinhardtii, and $E$. coli is very important for their effective antimicrobial action. A series of polyelectrolyte-coated $\mathrm{Mg}(\mathrm{OH})_{2} \mathrm{NPs}$ were likewise synthesised while using the layer by-layer technique and their antimicrobial activity towards S. cerevisiae, C. reinhardtii, and E. coli was compared with that of bare $\mathrm{Mg}(\mathrm{OH})_{2} \mathrm{NPs}$ in order to evaluate the role of the surface coating. It was discovered that the antimicrobial activity of the coated $\mathrm{Mg}(\mathrm{OH})_{2} \mathrm{NPs}$ alternates with their surface charge. The anionic nanoparticles $\left(\mathrm{Mg}(\mathrm{OH})_{2} \mathrm{NPs} / \mathrm{PSS}\right)$ have much lower antibacterial activity than the cationic ones $\left(\mathrm{Mg}(\mathrm{OH})_{2} \mathrm{NPs} / \mathrm{PSS} / \mathrm{PAH}\right.$ and bare $\left.\mathrm{Mg}(\mathrm{OH})_{2} \mathrm{NPs}\right)$. We also show that $\mathrm{Mg}(\mathrm{OH})_{2} \mathrm{NPs} / \mathrm{PSS} / \mathrm{PAH}$ and bare $\mathrm{Mg}(\mathrm{OH})_{2} \mathrm{NPs}$ have only very minor impact on selected human cells line (HEK293), which implies good biocompatibility. This can bring important insights as to how the antmicrobial properties of $\mathrm{Mg}(\mathrm{OH})_{2} \mathrm{NPs}$ and other inorganic nanoparticles can be controlled by designing nanoparticle surface coatings that promote their adhesion to the microbial cell walls, as well as by taking into account the nanoparticles surface morphology.

Supplementary Materials: The following are available online at http://www.mdpi.com/2313-7673/4/2/41/s1, Figure S1. A schematic overview summarizing the synthesis method of $\mathrm{Mg}(\mathrm{OH})_{2} \mathrm{NPs}$, Figure S2. Particle size of $\mathrm{Mg}(\mathrm{OH})_{2} \mathrm{NPs}$ made from magnesium chloride at $75^{\circ} \mathrm{C}$, Figure S3. The zeta potential of $\mathrm{Mg}(\mathrm{OH})_{2} \mathrm{NPs}$ made from magnesium chloride at $75^{\circ} \mathrm{C}$, Figure S4. (A) Thermal gravimetric analysis pattern of $\mathrm{Mg}(\mathrm{OH})_{2} \mathrm{NPs}$ powder. (B) The EDX spectra of the uncoated $\mathrm{Mg}(\mathrm{OH})_{2} \mathrm{NPs}$. (C) The impact of reaction temperature on the size of the produced $\mathrm{Mg}(\mathrm{OH})_{2} \mathrm{NPs}$. (D) Variations in particle size and zeta potential of $\mathrm{Mg}(\mathrm{OH})_{2} \mathrm{NPs}$ suspensions with pH, Figure S5. FTIR spectra of the as prepared $\mathrm{Mg}(\mathrm{OH})_{2} \mathrm{NPs}$ at different reaction temperatures, Figure S6. EDX diagram of S. cerevisiae cells at $1000 \mu \mathrm{g} \mathrm{mL}{ }^{-1}$, Figure S7. EDX chart of the C. reinhardtii with $\mathrm{Mg}(\mathrm{OH})_{2} \mathrm{NPs}$ at $1000 \mu \mathrm{g}$ $\mathrm{mL}^{-1}$, Figure S8. EDX chart of the C. reinhardtii with $\mathrm{Mg}(\mathrm{OH})_{2} \mathrm{NPs}$ at $5000 \mu \mathrm{g} \mathrm{mL}^{-1}$, Figure S9. EDX diagram of E. coli cells incubated with $\mathrm{Mg}(\mathrm{OH})_{2} \mathrm{NPs}$ at $2500 \mu \mathrm{g} \mathrm{mL} \mathrm{m}^{-1}$ and $5000 \mu \mathrm{g} \mathrm{mL}{ }^{-1}$, Figure S10. Schematic overview of the bacterial cell wall, Figure S11. The antibacterial impact of various concentration of $\mathrm{MgCl}_{2}$ towards E. coli for various exposure times, Figure S12. S. cerevisiae cell viability after incubation as a function of nanoparticle concentration for up to $24 \mathrm{~h}$ with uncoated and polyelectrolyte-coated $\mathrm{Mg}(\mathrm{OH})_{2} \mathrm{NPs}$; Figure S13. The antialgal activity of uncoated and polyelectrolyte-coated $\mathrm{Mg}(\mathrm{OH})_{2} \mathrm{NPs}$, Figure S14. Relationship between the antibacterial efficiency of uncoated and polyelectrolyte-coated $\mathrm{Mg}(\mathrm{OH})_{2} \mathrm{NPs}$ on the viability of E. coli., Figure S15. Colony forming unit (CFU) count of bare $\mathrm{Mg}(\mathrm{OH})_{2} \mathrm{NPs}$ on (A) S. cerevisiae (B) C. reinhardtii and (C) E. coli at various particle concentrations, Figure S16. Colony forming unit (CFU) count of S. cerevisiae as a function of nanoparticle concentration after incubation for up to 24 hours with (A) $\mathrm{Mg}(\mathrm{OH})_{2} \mathrm{NPs} / \mathrm{PSS}$ and (B) $\mathrm{Mg}(\mathrm{OH})_{2} \mathrm{NPs} / \mathrm{PSS} / \mathrm{PAH}$, Figure S17. Colony forming unit (CFU) count of $C$. reinhardtii as a function of nanoparticle concentration after incubation for up to $6 \mathrm{~h}$ with (A) $\mathrm{Mg}(\mathrm{OH})_{2} \mathrm{NPs} / \mathrm{PSS}$ and (B) $\mathrm{Mg}(\mathrm{OH})_{2} \mathrm{NPs} / \mathrm{PSS} / \mathrm{PAH}$, Figure S18. Colony forming unit (CFU) count of $E$. coli after treatment with $(\mathrm{A}) \mathrm{Mg}(\mathrm{OH})_{2} \mathrm{NPs} / \mathrm{PSS}$ and $(\mathrm{B}) \mathrm{Mg}(\mathrm{OH})_{2} \mathrm{NPs} / \mathrm{PSS} / \mathrm{PAH}$ for various incubation times as a function of the NPs concentration, Figure S19. Comparison of the cell viability of human embryonic kidney cells (HEK 293 cell line) upon incubation as a function of nanoparticle concentration for up to $24 \mathrm{~h}$ with bare $\mathrm{Mg}(\mathrm{OH})_{2} \mathrm{NPs}$ and $\mathrm{Mg}(\mathrm{OH})_{2} \mathrm{NPs} / \mathrm{PSS} / \mathrm{PAH}$, Figure S20. Antibacterial activity of $\mathrm{SiO}_{2} \mathrm{NPs}$ at various 
concentrations on E. coli., Figure S21. The anti-yeast, anti-algal and antibacterial activity of free PAH at various concentrations on (A) S. cerevisiae, (B) C. reinhardtii (C) E. coli.

Author Contributions: The manuscript was written through contributions of all authors. V.N.P. gave the idea of the study, A.F.H. did the experimental work co-supervised on equal basis by V.N.P. and T.S.H., A.F.H. produced the figures and the initial draft which was edited and further improved by V.N.P. and T.S.H. All authors have given approval to the final version of the manuscript.

Funding: A.F.H. thanks the Iraqi Government, the Higher Committee for Education Development of Iraq and the University of Babylon, Iraq for the financial support for his PhD study during the work on this project.

Acknowledgments: The authors appreciate the technical help from Tony Sinclair and Ann Lowry at the University of Hull Microscopy Suite with the SEM and TEM sample preparation and imaging.

Conflicts of Interest: The authors declare no conflict of interest.

\section{References}

1. Lee, D.; Cohen, R.E.; Rubner, M.F. Antibacterial properties of Ag nanoparticle loaded multilayers and formation of magnetically directed antibacterial microparticles. Langmuir 2005, 21, 9651-9659. [CrossRef] [PubMed]

2. Rawlinson, L.A.B.; Ryan, S.M.; Mantovani, G.; Syrett, J.A.; Haddleton, D.M.; Brayden, D.J. Antibacterial effects of poly (2-(dimethylamino ethyl) methacrylate) against selected gram-positive and gram-negative bacteria. Biomacromolecules 2009, 11, 443-453. [CrossRef] [PubMed]

3. Muñoz-Bonilla, A.; Fernández-García, M. Polymeric materials with antimicrobial activity. Prog. Polym. Sci. 2012, 37, 281-339. [CrossRef]

4. Halbus, A.F.; Horozov, T.S.; Paunov, V.N. Strongly enhanced antibacterial action of copper oxide nanoparticles with boronic acid surface functionality. ACS Appl. Mater. Inter. 2019, 11, 12232-12243. [CrossRef] [PubMed]

5. Halbus, A.F.; Horozov, T.S.; Paunov, V.N. Self-grafting copper oxide nanoparticles show a strong enhancement of their anti-algal and anti-yeast action. Nanoscale Adv. 2019, 1, 2323-2336. [CrossRef]

6. Vatsha, B.; Tetyana, P.; Shumbula, P.M.; Ngila, J.C.; Sikhwivhilu, L.M.; Moutloali, R.M. Effects of precipitation temperature on nanoparticle surface area and antibacterial behaviour of $\mathrm{Mg}(\mathrm{OH})_{2}$ and $\mathrm{MgO}$ nanoparticles. J. Biomater. Nanobiotechnol. 2013, 4, 365-373. [CrossRef]

7. Al-Obaidy, S.S.; Halbus, A.F.; Greenway, G.M.; Paunov, V.N. Boosting the antimicrobial action of vancomycin formulated in shellac nanoparticles of dual-surface functionality. J. Mater. Chem. B. 2019, 7, 3119-3133. [CrossRef]

8. Weldrick, P.J.; Iveson, S.; Hardman, M.J.; Paunov, V.N. Breathing new life into old antibiotics: Overcoming antibacterial resistance by antibiotic-loaded nanogel carriers with cationic surface functionality. Nanoscale 2019, 11, 10472-10485. [CrossRef]

9. Halbus, A.F.; Horozov, T.S.; Paunov, V.N. Colloid particle formulations for antimicrobial applications. Adv. Colloid Interface Sci. 2017, 249, 134-148. [CrossRef]

10. Zhang, H.; Chen, B.; Banfield, J.F. Particle Size and pH Effects on Nanoparticle Dissolution. J. Phys. Chem. C 2010, 114, 14876-14884. [CrossRef]

11. Liu, J.; Aruguete, D.M.; Murayama, M.; Hochella, M.F., Jr. Influence of size and aggregation on the reactivity of an environmentally and industrially relevant nanomaterial (PbS). Environ. Sci. Technol. 2009, 43, 8178-8183. [CrossRef] [PubMed]

12. Zhang, Y.; Chen, Y.; Westerhoff, P.; Hristovski, K.; Crittenden, J.C. Stability of commercial metal oxide nanoparticles in water. Water Res. 2008, 42, 2204-2212. [CrossRef] [PubMed]

13. Petosa, A.R.; Jaisi, D.P.; Quevedo, I.R.; Elimelech, M.; Tufenkji, N. Aggregation and deposition of engineered nanomaterials in aquatic environments: Role of physicochemical interactions. Environ. Sci. Technol. 2010, 44, 6532-6549. [CrossRef] [PubMed]

14. Sada, E.; Kumazawa, H.; Sawada, Y.; Kondo, T. Simultaneous absorption of dilute nitric oxide and sulfur dioxide into aqueous slurries of magnesium hydroxide with added iron (II)-EDTA chelate. Ind. Eng. Chem. Process Des. Dev. 1982, 21, 771-774. [CrossRef]

15. Gui, H.; Zhang, X.; Dong, W.; Wang, Q.; Gao, J.; Song, Z.; Lai, J.; Liu, Y.; Huang, F.; Qiao, J. Flame retardant synergism of rubber and $\mathrm{Mg}(\mathrm{OH})_{2}$ in EVA composites. Polymer 2007, 48, 2537-2541. [CrossRef] 
16. Cao, H.; Zheng, H.; Yin, J.; Lu, Y.; Wu, S.; Wu, X.; Li, B. $\mathrm{Mg}(\mathrm{OH})_{2}$ complex nanostructures with superhydrophobicity and flame-retardant effects. J. Phys. Chem. C 2010, 114, 17362-17368. [CrossRef]

17. Pan, X.; Wang, Y.; Chen, Z.; Pan, D.; Cheng, Y.; Liu, Z.; Lin, Z.; Guan, X. Investigation of antibacterial activity and related mechanism of a series of nano- $\mathrm{Mg}(\mathrm{OH})_{2}$. ACS Appl. Mater. Interfaces 2013, 5, 1137-1142. [CrossRef]

18. Martin, P.D.; Schneck, D.W.; Dane, A.L.; Warwick, M.J. The effect of a combination antacid preparation containing aluminium hydroxide and magnesium hydroxide on rosuvastatin pharmacokinetics. Curr. Med. Res. Opin. 2008, 24, 1231-1235. [CrossRef]

19. Scott, G.; Reynolds, C.V.; Milosavljev, S.; Langholff, W.; Shenouda, M.; Rordorf, C. Lack of effect of omeprazole or of an aluminium hydroxide/magnesium hydroxide antacid on the pharmacokinetics of lumiracoxib. Clin. Pharmacokinet. 2004, 43, 341-348. [CrossRef]

20. Kang, J.; Schwendeman, S.P. Comparison of the effects of $\mathrm{Mg}(\mathrm{OH})_{2}$ and sucrose on the stability of bovine serum albumin encapsulated in injectable poly (D,L-lactide-co-glycolide) implants. Biomaterials 2002, 23, 239-245. [CrossRef]

21. Tong, K.; Song, X.; Xiao, G.; Yu, J. Colloidal processing of $\mathrm{Mg}(\mathrm{OH})_{2}$ aqueous suspensions using sodium polyacrylate as dispersant. Ind. Eng. Chem. Res. 2014, 53, 4755-4762. [CrossRef]

22. Waaijers, S.L.; Kong, D.; Hendriks, H.S.; de Wit, C.A.; Cousins, I.T.; Westerink, R.H.; Leonards, P.E.; Kraak, M.H.; Admiraal, W.; de Voogt, P. Persistence, bioaccumulation, and toxicity of halogen-free flame retardants. In Reviews of Environmental Contamination and Toxicology; Springer: New York, NY, USA, 2013; pp. 1-71.

23. Dong, C.; Song, D.; Cairney, J.; Maddan, O.L.; He, G.; Deng, Y. Antibacterial study of $\mathrm{Mg}(\mathrm{OH})_{2}$ nanoplatelets. Mater. Res. Bull. 2011, 46, 576-582. [CrossRef]

24. Dong, C.; Cairney, J.; Sun, Q.; Maddan, O.L.; He, G.; Deng, Y. Investigation of Mg $(\mathrm{OH})_{2}$ nanoparticles as an antibacterial agent. J. Nanopart. Res. 2010, 12, 2101-2109. [CrossRef]

25. Dong, C.; He, G.; Li, H.; Zhao, R.; Han, Y.; Deng, Y. Antifouling enhancement of poly (vinylidene fluoride) microfiltration membrane by adding $\mathrm{Mg}(\mathrm{OH})_{2}$ nanoparticles. J. Membr. Sci. 2012, 387, 40-47. [CrossRef]

26. Wang, Z.; Li, C.; Mu, Y.; Lin, Z.; Yi, A.; Zhang, Q.; Yan, B. Nanoadduct relieves: Alleviation of developmental toxicity of $\mathrm{Cr}(\mathrm{VI})$ due to its spontaneous adsorption to $\mathrm{Mg}(\mathrm{OH})_{2}$ nanoflakes. J. Hazard. Mater. 2015, 287, 296-305. [CrossRef] [PubMed]

27. Pilarska, A.; Bula, K.; Myszka, K.; Rozmanowski, T.; Szwarc-Rzepka, K.; Pilarski, K.; Chrzanowski, Ł.; Czaczyk, K.; Jesionowski, T. Functional polypropylene composites filled with ultra-fine magnesium hydroxide. Open Chem. 2015, 13, 161-171. [CrossRef]

28. Dong, C.; He, G.; Zheng, W.; Bian, T.; Li, M.; Zhang, D. Study on antibacterial mechanism of $\mathrm{Mg}(\mathrm{OH})_{2}$ nanoparticles. Mater. Lett. 2014, 134, 286-289. [CrossRef]

29. Li, Q.; Mahendra, S.; Lyon, D.Y.; Brunet, L.; Liga, M.V.; Li, D.; Alvarez, P.J. Antimicrobial nanomaterials for water disinfection and microbial control: Potential applications and implications. Water Res. 2008, 42, 4591-4602. [CrossRef]

30. Mendonca, A.F.; Amoroso, T.L.; Knabel, S.J. Destruction of gram-negative food-borne pathogens by high $\mathrm{pH}$ involves disruption of the cytoplasmic membrane. Appl. Environ. Microbiol. 1994, 60, 4009-4014.

31. Kumar, A.; Vemula, P.K.; Ajayan, P.M.; John, G. Silver-nanoparticle-embedded antimicrobial paints based on vegetable oil. Nat. Mater. 2008, 7, 236-241. [CrossRef]

32. Hoshino, A.; Fujioka, K.; Oku, T.; Suga, M.; Sasaki, Y.F.; Ohta, T.; Yasuhara, M.; Suzuki, K.; Yamamoto, K. Physicochemical properties and cellular toxicity of nanocrystal quantum dots depend on their surface modification. Nano Lett. 2004, 4, 2163-2169. [CrossRef]

33. Mudunkotuwa, I.A.; Grassian, V.H. Citric acid adsorption on $\mathrm{TiO}_{2}$ nanoparticles in aqueous suspensions at acidic and circumneutral $\mathrm{pH}$ : Surface coverage, surface speciation, and its impact on nanoparticlenanoparticle interactions. J. Am. Chem. Soc. 2010, 132, 14986-14994. [CrossRef] [PubMed]

34. LB (Luria-Bertani) liquid medium. Cold Spring Harb. Protoc. 2006. [CrossRef]

35. Al-Awady, M.J.; Greenway, G.M.; Paunov, V.N. Nanotoxicity of polyelectrolyte-functionalized titania nanoparticles towards microalgae and yeast: Role of the particle concentration, size and surface charge. RSC Adv. 2015, 5, 37044-37059. [CrossRef]

36. Yu, J.C.; Xu, A.; Zhang, L.; Song, R.; Wu, L. Synthesis and characterization of porous magnesium hydroxide and oxide nanoplates. J. Phys. Chem. B 2004, 108, 64-70. [CrossRef] 
37. Dhaouadi, H.; Chaabane, H.; Touati, $\mathrm{F} . \mathrm{Mg}(\mathrm{OH})_{2}$ nanorods synthesized by a facile hydrothermal method in the presence of CTAB. Nano Micro Lett. 2011, 3, 153-159. [CrossRef]

38. Meshkani, F.; Rezaei, M. Facile synthesis of nanocrystalline magnesium oxide with high surface area. Powder Technol. 2009, 196, 85-88. [CrossRef]

39. Pang, H.; Ning, G.; Gong, W.; Ye, J.; Lin, Y. Direct synthesis of hexagonal $\mathrm{Mg}(\mathrm{OH})_{2}$ nanoplates from natural brucite without dissolution procedure. Chem. Commun. 2011, 47, 6317-6319. [CrossRef]

40. Wu, X.F.; Hu, G.S.; Wang, B.B.; Yang, Y.F. Synthesis and characterization of superfine magnesium hydroxide with monodispersity. J. Cryst. Growth 2008, 310, 457-461. [CrossRef]

41. Brayner, R.; Ferrari-Iliou, R.; Brivois, N.; Djediat, S.; Benedetti, M.F.; Fiévet, F. Toxicological impact studies based on Escherichia coli bacteria in ultrafine $\mathrm{ZnO}$ nanoparticles colloidal medium. Nano Lett. 2006, 6, 866-870. [CrossRef]

42. Lin, W.; Xu, Y.; Huang, C.C.; Ma, Y.; Shannon, K.B.; Chen, D.R.; Huang, Y.W. Toxicity of nano-and micro-sized ZnO particles in human lung epithelial cells. J. Nanopart. Res. 2009, 11, 25-39. [CrossRef]

43. Sondi, I.; Salopek-Sondi, B. Silver nanoparticles as antimicrobial agent: A case study on E. coli as a model for Gram-negative bacteria. J. Colloid Interface Sci. 2004, 275, 177-182. [CrossRef] [PubMed]

44. Al-Awady, M.J.; Fauchet, A.; Greenway, G.M.; Paunov, V.N. Enhanced antimicrobial effect of berberine in nanogel carriers with cationic surface functionality. J. Mater. Chem. B 2017, 5, 7885-7897. [CrossRef]

45. Al-Awady, M.J.; Weldrick, P.J.; Hardman, M.J.; Greenway, G.M.; Paunov, V.N. Amplified antimicrobial action of chlorhexidine encapsulated in PDAC-functionalized acrylate copolymer nanogel carriers. Mater. Chem. Front. 2018, 2, 2032-2044. [CrossRef]

46. Franklin, N.M.; Rogers, N.J.; Apte, S.C.; Batley, G.E.; Gadd, G.E.; Casey, P.S. Comparative toxicity of nanoparticulate $\mathrm{ZnO}$, bulk $\mathrm{ZnO}$, and $\mathrm{ZnCl}_{2}$ to a freshwater microalga (Pseudokirchneriella subcapitata): The importance of particle solubility. Environ. Sci. Technol. 2007, 41, 8484-8490. [CrossRef] [PubMed]

47. Heinlaan, M.; Ivask, A.; Blinova, I.; Dubourguier, H.C.; Kahru, A. Toxicity of nanosized and bulk ZnO, CuO and $\mathrm{TiO}_{2}$ to bacteria Vibrio fischeri and crustaceans Daphnia magna and Thamnocephalus platyurus. Chemosphere 2008, 71, 1308-1316. [CrossRef] [PubMed]

48. Choi, O.; $\mathrm{Hu}, \mathrm{Z}$. Size dependent and reactive oxygen species related nanosilver toxicity to nitrifying bacteria. Environ. Sci. Technol. 2008, 42, 4583-4588. [CrossRef] [PubMed]

49. Pan, Y.; Neuss, S.; Leifert, A.; Fischler, M.; Wen, F.; Simon, U.; Schmid, G.; Brandau, W.; Jahnen-Dechent, W. Size-dependent cytotoxicity of gold nanoparticles. Small 2007, 3, 1941-1949. [CrossRef]

50. Al-Obaidy, S.S.; Greenway, G.M.; Paunov, V.N. Dual-functionalised shellac nanocarriers give a super-boost of the antimicrobial action of berberine. Nanoscale Adv. 2019, 1, 858-872. [CrossRef]

51. Chen, P.; Powell, B.A.; Mortimer, M.; Ke, P.C. Adaptive interactions between zinc oxide nanoparticles and Chlorella sp. Environ. Sci. Technol. 2012, 46, 12178-12185. [CrossRef] 